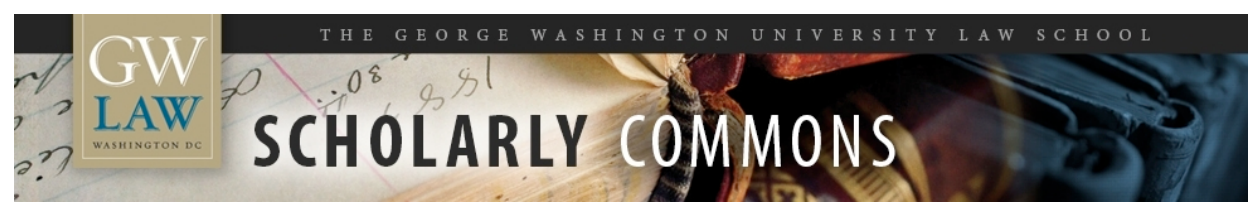

\title{
Cuomo v. Clearing House: The Supreme Court Responds to the Subprime Financial Crisis and Delivers a Major Victory for the Dual Banking System and Consumer Protection
}

Arthur E. Wilmarth Jr.

George Washington University Law School, awilmarth@law.gwu.edu

Follow this and additional works at: https://scholarship.law.gwu.edu/faculty_publications

Part of the Law Commons

\section{Recommended Citation}

Arthur E. Wilmarth Jr., Cuomo v. Clearing House: The Supreme Court Responds to the Subprime Financial Crisis and Delivers a Major Victory for the Dual Banking System and Consumer Protection in THE PANIC OF 2008: CAUSES, CONSEQUENCES AND IMPLICATIONS FOR REFORM (Lawrence E. Mitchell and Arthur E. Wilmarth Jr., eds., Edward Elgar Publishing, 2010).

This Book Part is brought to you for free and open access by the Faculty Scholarship at Scholarly Commons. It has been accepted for inclusion in GW Law Faculty Publications \& Other Works by an authorized administrator of Scholarly Commons. For more information, please contact spagel@law.gwu.edu. 
Forthcoming in Lawrence E. Mitchell \& Arthur E. Wilmarth, Jr., eds., The PANIC OF 2008:

Causes, Consequences and Implications for Reform (Edward Elgar Publishing, 2010)

Cuomo v. Clearing House: The Supreme Court Responds to the Subprime Financial Crisis and Delivers a Major Victory for the Dual Banking System and Consumer Protection

Arthur E. Wilmarth, Jr.*

\section{INTRODUCTION}

In Cuomo v. Clearing House Ass' $n$, L.L.C., ${ }^{1}$ the Supreme Court held that the Office of the Comptroller of the Currency (OCC) exceeded its authority when it adopted a regulation (12

C.F.R. $\S 7.4000)$ that prohibited state officials from filing lawsuits to enforce applicable state laws against national banks. The Court upheld the OCC's regulation only to the extent that it bars state authorities from bringing administrative enforcement proceedings against national banks. Thus, the Court drew a clear distinction between "administrative oversight" of national banks by state officials - which the Court viewed as preempted by the National Bank Act (NBA) - and "judicial enforcement actions" against national banks by state officials, which the Court found to be consistent with the NBA and the Court's prior decisions. ${ }^{2}$

Cuomo arose out of an attempt by the New York Attorney General (NYAG) to enforce New York's fair lending laws against several large national banks that were heavily engaged in nonprime mortgage lending. By affirming New York's authority to enforce its fair lending laws against national banks through the courts, the Supreme Court exhibited a perspective on banking regulation that sharply contrasted with the Court's approach only two years earlier in Watters $v$. Wachovia Bank, N.A. ${ }^{3}$ In Watters, the Court upheld another OCC regulation (12 C.F.R.

\footnotetext{
* Professor of Law, George Washington University Law School. I wish to thank the Law School and Dean Fred Lawrence for a summer research grant that supported my work on this book chapter. I also wish to express my appreciation for the excellent research assistance provided by Christopher Scott Pollock, a member of our Law School's Class of 2010, and by Germaine Leahy, Head of Reference for the Jacob Burns Law Library. I was the principal author of an amicus brief that was filed in the Cuomo case by an association of state financial regulators in support of New York Attorney General Andrew Cuomo.

1129 S. Ct. 2710 (2009).

2 Id. at 2721-22.

3550 U.S. 1 (2007).
} 
$\S 7.4006)$, which preempted the application of state laws to nonbank mortgage lending subsidiaries of national banks.

Watters took a broad view of the preemptive reach of the NBA and indicated that national banks would not benefit from any supplemental regulation by the states. In Cuomo, however, the Court took great pains to limit the scope and precedential force of Watters. Moreover, Cuomo indicated a renewed appreciation for the historic role of the states in regulating financial institutions and protecting consumers. Three members of the Supreme Court (Justices Ginsburg, Breyer and Souter) switched from supporting the OCC in Watters to opposing the OCC in Cuomo. Evidently, their positions changed because they modified their views about the merits of the OCC's preemptive regime and the value of state regulation between April 2007, when Watters was decided, and June 2009, when Cuomo was issued.

The most plausible explanation for the three Justices' change in perspective is that they were influenced by the outbreak of the subprime financial crisis in August 2007 and by subsequent federal bailouts of several major national banks that were deeply involved in nonprime lending. Amicus briefs filed in support of the NYAG included numerous references to the financial crisis. In addition, the briefs sharply criticized the OCC for its sweeping preemption of state law and for its weak record of protecting consumers from abusive lending practices. My hypothesis that the financial crisis and its aftermath influenced the Court's decision in Cuomo is necessarily based on inference, because the majority opinion in Cuomo did not specifically refer to those events. However, statements made by Justices Ginsburg, Souter and Stevens during oral argument in Cuomo, and by Justice Stevens in his dissenting opinion in Watters, indicate that the Court was aware of the mortgage crisis and the growing controversy over the OCC's preemptive actions.

Cuomo provides much-needed judicial support for (i) the principles of regulatory federalism inherent in the dual banking system and (ii) the importance of consumer protection in preserving financial stability. Cuomo undermines the legal rationale for several of the OCC's 
other preemption rules, and Cuomo reaffirms earlier Supreme Court precedents that upheld the general applicability of state laws to national banks. Cuоmo also supports legislative proposals recently advanced by the Obama administration, which seek to preserve the states' longstanding role in protecting consumers of financial services.

During the past decade, the states have been far more proactive than the OCC and other federal agencies in enacting laws and bringing enforcement proceedings to protect consumers against predatory lending and other abusive financial practices. The subprime financial crisis has demonstrated that effective consumer protection (including the prevention of predatory lending) is closely linked to the safety and soundness of financial institutions. The states' favorable record of legislation and enforcement over the past decade has confirmed the wisdom of preserving a federalist system of financial regulation, which includes not only a federal component but also a supplemental state role in enacting and enforcing consumer protection laws.

The only disappointing aspect of Cuomo for the states is that the Supreme Court failed to resolve a recurring issue about the appropriate level of judicial deference that federal agencies should receive when they claim authority to preempt state law. Cuomo did not follow a relatively demanding, four-part framework for judicial review of agency preemption claims that was suggested in Justice Stevens' opinion for the Court in Wyeth v. Levine. ${ }^{4}$ As explained below, that four-part framework would strike an appropriate balance between (i) the expectation that administrative agencies should receive some deference based on their specialized expertise and (ii) the judiciary's responsibility to en sure that preemption issues are resolved in accordance with the Constitution's allocation of federal and state powers..

Cuomo instead left open the possibility that future preemption claims by federal agencies could receive a higher level of judicial deference under Chevron U.S.A. Inc. v. National Resources Defense Council. ${ }^{5}$ However, the Supreme Court in Cuomo refused to defer to the

4 129 S. Ct. 1187 (2009).

5467 U.S. 837 (1984). 
OCC's preemptive rule, based on the Court's conclusion that Congress did not delegate the preemptive power asserted by the OCC. Cuomo may indicate that, even if the Court chooses to apply Chevron in future cases involving agency preemption claims, the Court will apply a heightened level of scrutiny under Chevron, particularly with regard to the issue of whether Congress has affirmatively delegated the preemptive authority alleged by the agency. While Cuomo does not resolve this important question, Cuomo's broader context reveals that the policies of all three branches of the federal government have been deeply implicated by the ongoing financial crisis.

\section{Factual and Legal Background of Cuomo v. Clearing House}

In 2005, NYAG Eliot Spitzer sent informal letters of inquiry to several large national banks that were members of The Clearing House Association, L.L.C. (Clearing House). The recipients of Mr. Spitzer's letters included Citigroup, HSBC, JP Morgan Chase and Wells Fargo. Mr. Spitzer's letters were based on his office's preliminary analysis of residential mortgage lending data that the banks released to the public pursuant to the federal Home Mortgage Disclosure Act (HMDA). The banks' HMDA data "appeared to indicate that a significantly higher percentage of high-interest home mortgage loans [were] issued to African-American and Hispanic borrowers than to white borrowers." ${ }^{\prime 6}$ Mr. Spitzer's letters declared that such disparities "are troubling on their face, and unless legally justified may violate federal and state antidiscrimination laws such as the Equal Credit Opportunity Act [(ECOA)] and its state counterpart, New York State Executive Law § 296-a."” Like ECOA, § 296-a "broadly prohibits creditors from discriminating on the basis of sex, national origin, or other protected grounds." Mr. Spitzer stated that he was sending his letters "[i]n lieu of issuing a formal subpoena," and he

${ }^{6}$ Clearing House Ass'n, L.L.C. v. Cuomo, 510 F.3d 105, 109 (2d Cir. 2007), aff'd in part, rev'd in part, 129 S. Ct. 2710 (2009).

${ }^{7} \mathrm{Id}$.

${ }^{8}$ Id. at 109 n. 3. 
requested that the recipients voluntarily provide non-public information concerning their residential mortgage lending policies and practices in New York. ${ }^{9}$

The OCC and the Clearing House acknowledged that N.Y. Executive Law § 296-a was not preempted by federal law and therefore applied to national banks. ${ }^{10}$ This acknowledgment was consistent with ECOA, which authorizes the states to adopt laws prohibiting discrimination in lending that are equivalent to, or more protective than, the federal statute. ${ }^{11}$ The OCC had previously conceded in March 2004 that state antidiscrimination laws were not substantively preempted by regulations issued by the OCC in January of that year. The OCC made its concession in response to an inquiry from Representative Barney Frank, the ranking member of the House Financial Services Committee, who strongly criticized the OCC's preemption rules. ${ }^{12}$ Notwithstanding the conceded applicability of N.Y. Executive Law $§ 296$-a to national banks, the OCC and the Clearing House sued Mr. Spitzer and asserted that 12 C.F.R. $\S 7.4000$ preempted his authority to enforce the New York statute against national banks through either administrative or judicial proceedings. Both parties alleged that any investigative or enforcement efforts by Mr. Spitzer would constitute "visitorial" activities and would therefore be preempted by $\S 7.4000$. The district court enjoined Mr. Spitzer from pursuing any type of administrative or judicial enforcement proceedings against the Clearing House's member banks. The district court's decision was subsequently affirmed by a divided panel of the Second Circuit Court of

\footnotetext{
${ }^{9}$ Id. at 109.

10 See id. at $114,120$.

11 ECOA prohibits all "creditors" - a category that includes national banks - from discriminating in credit transactions on the basis of several characteristics, including race and national origin. 15 U.S.C. $\S$ 1691(a), 1691a(e). ECOA expressly preserves the states' authority to enact laws prohibiting lending discrimination that are consistent with the federal statute. In this regard, ECOA specifically affirms the states' power to adopt laws that give "greater protection" to borrowers than is afforded under ECOA. Id. § $1691 \mathrm{~d}(\mathrm{f})$.

12 OCC Interpretive Letter No. 998 (letter from OCC Chief Counsel Julie L. Williams to Rep. Barney Frank dated Mar. 9, 2004). For an analysis and critique of the OCC's 2004 preemption rules, see Arthur E. Wilmarth, Jr., “The OCC's Preemption Rules Exceed the Agency's Authority and Present a Serious Threat to the Dual Banking System and Consumer Protection," 23 Annual Review of Banking and Financial Law 225 (2004), available at http://ssrn.com/abstract=577863. See also infra notes 89-90, 224-29 and accompanying text (discussing the OCC's preemption rules); Karen L. Werner, "Preemption: Frank, House Democrats Urge OCC to Delay Effective Date of Rulemaking," 92 Banking Report (BNA) 283 (Feb. 16, 2004) (describing Rep. Frank's opposition to the OCC's preemption rules).
} 
Appeals. ${ }^{13}$ The Supreme Court granted the petition for certiorari filed by Mr. Spitzer's successor, NYAG Andrew Cuomo.

\section{The OCC's Regulation and the Definition of "Visitorial Powers"}

The OCC's regulation at issue in Cuomo prohibited state officials from exercising "visitorial powers" over national banks. The regulation defined "visitorial powers" to include any attempt by state officials to conduct investigations or enforce state laws with respect to "activities authorized or permitted [to national banks] pursuant to federal banking law." 12 C.F.R. $\S 7.4000$ (a). In January 2004, the OCC amended the regulation by extending its ban on state enforcement actions to reach judicial as well as administrative proceedings. ${ }^{14}$ The OCC thus claimed authority to bar state officials from using any forum - including the courts - to enforce applicable state laws against national banks.

The question presented in Cuomo was whether the OCC's expansive definition of "visitorial powers" was authorized by the NBA. In answering that question, the Supreme Court applied "the familiar Chevron framework" to determine whether the Court should defer to the OCC's regulation as a lawful interpretation of the NBA. ${ }^{15}$ The Court held, in a 5-4 decision authored by Justice Scalia, that the OCC's regulation exceeded the agency's authority to the extent that it barred state officials from filing lawsuits to enforce valid, non-preempted state laws against national banks.

The relevant provision of the NBA, 12 U.S.C. $\S 484(a)$, states that " $[n]$ o national bank shall be subject to any visitorial pow ers except as authorized by Federal law, vested in the courts of justice or ... exercised or directed by Congress or by either House thereof or by [an authorized congressional committee].” The NBA has included a provision similar to $§ 484$ (a) since its

${ }^{13}$ Cuomo, 510 F.3d at 109-10. The district court also enjoined NYAG Spitzer from suing national banks under the Federal Housing Act ("FHA") in the state's capacity as parens patriae on behalf of New York citizens. The Second Circuit vacated that portion of the district court's decision, concluding that the district court did not have jurisdiction to decide the FHA issues due to lack of ripeness. Id. at 110, 121-26.

${ }^{14} 69$ Federal Register 1895, 1904 (2004) (amending 12 C.F.R. $§ 7.4000$ ); see id. at 1895 (declaring that "state authorities may not achieve indirectly by resort to judicial actions what [the NBA] prohibits them from achieving directly through state regulatory or supervisory mechanisms").

15 Cuomo, 129 S. Ct. at 2715. 
original enactment in $1864 .{ }^{16}$ Neither $\S 484$ (a) nor any other section of the NB A defines the term "visitorial powers." The majority opinion in Cuomo acknowledged that "[t]there is necessarily some ambiguity as to the meaning of the statutory term 'visitorial powers,' especially since we are working in an era when the prerogative writs - through which visitorial powers were traditionally enforced - are not in vogue." ${ }^{17}$ However, Justice Scalia concluded that "[w]e can discern the outer limits of the term 'visitorial powers' even through the clouded lens of history," based on "[e]vidence from the time of the statute's enactment, a long line of our own cases, and application of normal principles of construction to the [NBA]."18

The majority and dissenting opinions in Cuomo strongly disagreed over the historical understanding of the term "visitorial powers." In the majority's view, "[o]ur cases have always understood 'visitation' as [the] right to oversee corporate affairs, quite separate from the power to enforce the law."19 As support for this historical distinction, the majority cited Justice Story's concurring opinion in the Supreme Court's 1819 decision in Dartmouth College. In that case, Justice Story observed that chancery courts possessed "a general jurisdiction . . . to redress grievances and fraud" committed by a corporation, but Story explained that the jurisdiction of chancery courts was not a "visitorial power" and was separate from the "controlling authority of [the corporation's] legal visitor." ${ }^{20}$

In his dissenting opinion in Cuomo, Justice Thomas attempted to distinguish Dartmouth College on the ground that the college was a charitable rather than a civil (for profit) corporation. Justice Thomas argued that visitors of charitable corporations historically did not have law enforcement powers, while visitors of civil corporations did possess such powers. Therefore, he

\footnotetext{
16 See Act of June 3, 1864, c. 78, § 54, 13 Stat. 116.

17 Cuomo, 129 S. Ct. at 2715. In his dissenting opinion in Cuomo, Justice Thomas agreed that the term "visitorial powers" was "ambiguous." However, he argued that, under Chevron, the ambiguity of the statute required the Court to defer to the OCC's "reasonable" interpretation of the term. Id. at 2723, 273233 (Thomas, J., concurring in part and dissenting in part).

${ }^{18} I d$ at 2715.

19 Id. at 2716.

${ }^{20}$ Id. at 2716 (quoting Trustees of Dartmouth College v. Woodward, 17 U.S. (4 Wheat.) 518, 676 (1819) (Story, J., concurring)).
} 
contended, Justice Story's opinion in Dartmouth College did not contradict the OCC's position that all law enforcement activities directed at for profit corporations (including national banks) should be viewed as "visitorial." 21 Justice Scalia responded to this argument by denying the significance of any difference between visitors of charitable and for profit corporations. He concluded that "whether or not visitors of charitable corporations had law-enforcement powers, the powers that they did possess demonstrate that visitation is different from ordinary law enforcement." 22

In a 1936 law review article, Dean Roscoe Pound pointed out that there was a division of opinion in both England and the United States on the question of whether courts of equity possessed a power to enforce laws against corporations that was independent of the "visitorial" powers held by the sovereign chartering authority (namely, the British monarch or the national and state governments of the United States). As Dean Pound explained, the sovereign chartering authority had the unquestioned right to exercise "visitorial" powers either administratively or by invoking the jurisdiction of common law courts through the prerogative writs of mandamus, scire facias and quo warranto. In contrast, the law enforcement jurisdiction of equity courts over corporations was not universally recognized. Nevertheless, a number of authorities in both England and America held that equity courts did have an independent power to enforce applicable laws against corporations, as indicated by Justice Story's concurring opinion in Dartmouth College. ${ }^{23}$ Dean Pound noted that the NBA appeared to recognize the independent enforcement power of equity courts by providing that the limitation on "visitorial powers" under $\S 484($ a) would not extinguish powers "vested in the courts of justice."24

${ }^{21} I d$. at 2724-25 \& n.1 (Thomas, J., concurring in part and dissenting in part).

${ }^{22} I d$. at 2716 n.1 (majority opinion).

${ }^{23}$ Roscoe Pound, "Visitatorial Jurisdiction over Corporations in Equity," 49 Harvard Law Review 369 (1936). Surprisingly, Dean Pound's article did not discuss or even cite Justice Story's opinion in Dartmouth College.

${ }^{24}$ Id. at 389 (citing Rev. Stat. § 5241 (codified as amended at 12 U.S.C. § 484(a)). An antecedent of the "vested in the courts of justice" clause appeared in $\S 54$ of the original NBA of 1864 . Section 54 provided that the powers "vested in the several courts of law and chancery" would not be disturbed by the general restriction on the exercise of "visitorial powers" over national banks. Act of June 3, 1864, c. 78, §54, 13 Stat. 116. 
The majority opinion in Cuomo agreed that a decision in favor of allowing state officials to sue national banks was "suggested" by the "vested in the courts of justice" clause in $\S 484(a){ }^{25}$ In Justice Scalia's view, that provision's “only conceivable purpose is to preserve normal civil and criminal lawsuits.... [I]t is explicable only as an attempt to make clear that the court's ordinary powers of enforcing the law are not affected." 26

The majority opinion in Cuomo relied heavily on two Supreme Court decisions from the first quarter of the twentieth century - Guthrie v. Harkness ${ }^{27}$ and First National Bank in St. Louis v. Missouri. ${ }^{28}$ Guthrie held that a shareholder's suit against a national bank to en force his right to inspect corporate records did not involve a prohibited exercise of "visitorial" powers. In Cuomo, Justice Scalia pointed out that Guthrie "drew a contrast between the nonvisitorial act of "su[ing] in the courts of the State' and the visitorial 'supervision of the [OCC]." 29 The Court in Guthrie placed substantial weight on the "courts of justice" clause, observing that "powers . . 'vested in the courts of justice' ... are expressly excepted from the inhibition of [§ 484(a)]." ${ }^{30}$

St. Louis upheld the right of Missouri (through its attorney general) to bring a quo warranto action in state court against a national bank for violating Missouri's anti-branching law. ${ }^{31}$ The Court determined in St. Louis that the NBA (as of 1924) did not authorize national banks to establish branches, except in narrowly limited circumstances that were not relevant to the case. Accordingly, the Court held that since "the power sought to be exercised by the bank finds no justification in any law or authority of the United States, the way is open for the enforcement of the state statute." 32 The Court rejected the national bank's claim (supported by

${ }^{25}$ Cuomo, 129 S. Ct. at 2718.

${ }^{26} I d$.

27199 U.S. 148 (1905).

28263 U.S. 640 (1924).

29 Cuomo, 129 S. Ct. at 2717 (quoting Guthrie, 199 U.S. at 159).

${ }^{30}$ Guthrie, 199 U.S. at 159.

31 St. Louis, 263 U.S. at 655 (explaining that "the State of Missouri brought this proceeding in the nature of quo warranto in the State Supreme Court against the [national bank] to determine its authority to establish and conduct a branch bank in the City of St. Louis. .. . The prayer is that, upon final hearing, the bank be ousted from the privilege of operating this branch bank or any other").

${ }^{32}$ Id. at 660 . 
the United States) that the federal government had exclusive authority to bring a quo warranto action to enforce Missouri's law against the bank. As Justice Scalia explained in Cuomo, the Court in St. Louis affirmed that "only the United States may perform visitorial administrative oversight" over national banks, but "if a state statute of general applicability is not substantively pre-empted, then 'the power of enforcement must rest with the [State] and not with' the National Government." ${ }^{33}$ Justice Scalia concluded that "St. Louis is one of a long and unbroken line of cases distinguishing visitation from law enforcement." ${ }^{34}$

Dean Pound observed that the decision in St. Louis was highly significant in upholding the authority of a state to maintain a quo warranto action against a national bank that the state did not charter. ${ }^{35}$ St. Louis cited, and was consistent with, the Supreme Court's earlier decision in Standard Oil Co. v. Missouri. ${ }^{36}$ In Standard Oil, the Court affirmed the right of Missouri (through its attorney general) to prosecute a quo warranto proceeding in state court against two out-of-state corporations that violated Missouri's antitrust statute. ${ }^{37}$ As Dean Pound pointed out, Missouri's independent authority to sue the national bank in St. Louis was analogous to Missouri's power to sue the two foreign corporations in Standard Oil, because Missouri was not the chartering authority for any of the three corporations and therefore did not possess visitorial powers over them. ${ }^{38}$

The majority opinion in Cuomo next turned to the Supreme Court's 2007 decision in Watters. Watters held that the NBA preempted the application of Michigan's laws governing nonbank mortgage lenders to operating subsidiaries of national banks. ${ }^{39}$ In Cuomo, Justice Scalia

${ }^{33}$ Cuomo, 129 S. Ct. at 2717 (quoting St. Louis, 263 U.S. at 660).

${ }^{34} I d$. at 2717 n. 2.

35 Pound, supra note 23, at 389.

36224 U.S. 270 (1912).

37 Id. at 272 (explaining that Missouri's quo warranto action requested that "each of the defendants be ousted of their corporate franchises and license to do business under the laws of [Missouri]" because they entered into a combination that illegally sought to restrain trade in Missouri). In St. Louis, the Supreme Court cited Standard Oil to support its conclusion that a quo warranto proceeding was consistent with Missouri law and did not result in a denial of due process. St. Louis, 263 U.S. at 661 (citing Standard Oil).

${ }^{38}$ Pound, supra note 23, at 389.

39 Watters, 550 U.S. at 15-21. 
maintained that Watters "is fully in accord with the well established distinction between supervision and law enforcement. ... All parties to the case agreed that Michigan's general oversight regime could not be imposed on national banks; the sole question was whether operating subsidiaries of national banks enjoyed the same immunity from state visitation." 40 Justice Scalia emphasized that Watters "addresses and answers no other question." 41

Based upon its review of the Court's previous cases dealing with "visitorial" powers, the majority opinion in Cuomo concluded that "the unmistakable and utterly consistent teaching of our jurisprudence, both before and after enactment of the [NBA], is that a sovereign's 'visitorial powers' and its power to enforce the law are two different things.... [C]ontrary to what the [OCC's] regulation says, the [NBA] pre-empts only the former."42

Accordingly, Cuomo held that "visitorial powers . . . include any form of administrative oversight that allows a sovereign to inspect books and records on demand."43 In contrast, a lawsuit by a state attorney general to enforce state law "is not an exercise of 'visitorial powers' and thus the [OCC] erred by extending the definition of 'visitorial powers' to include 'prosecuting enforcement actions' in state courts." 44 The Supreme Court upheld the Second Circuit's judgment "as applied to the threatened is suance of executive subpoenas" by the NYAG, but the Supreme Court reversed the lower court's judgment "insofar as it prohibits the [NYAG] from bringing judicial enforcem ent actions." 45

Justice Scalia emphasized the "pragmatic" significance of the majority opinion's distinction between visitation and judicial enforcement. The $\mathrm{OCC}$ as visitor "may inspect books

\footnotetext{
40 Cuomo, 129 S. Ct. at 2717.

${ }^{41} I d$.

${ }^{42} I d$. In this regard, the majority cited cases finding that "law enforcement by federal agencies" against national banks did not constitute a prohibited exercise of "visitorial" powers. Id. (citing two lower court opinions). The majority subsequently cited additional cases to show that "States . . have always enforced their general laws against national banks - and have enforced their banking-related laws against national banks for at least 85 years, as evidenced by St. Louis." Id. at 2720-21 (citing, inter alia, Anderson National Bank v. Luckett, 321 U.S. 233, 237, 248-49 (1944)).

${ }^{43}$ Id. at 2721.

${ }^{44} I d$.

${ }^{45}$ Id. at 2722.
} 
and records at any time for any or no reason." ${ }^{46}$ In contrast, a state "attorney general acting as a civil litigant must file a lawsuit, survive a motion to dismiss, endure the rules of procedure and discovery, and risk sanctions if his claims are frivolous or his discovery tactics abusive."47 Courts could also enter protective orders to prevent unreasonable expense or prejudice to national banks. In Justice Scalia's view, courts could be "trusted to prevent 'fishing expeditions' or an undirected rummaging through bank books" by state officials. ${ }^{48}$

\section{The Dramatic Contrast between Cuomo and Watters}

The majority opinion in Cuomo sharply limited the scope and precedential effect of the Court's previous opinion in Watters. As noted above, Cuomo declared that the "sole question" decided in Watters was "whether operating subsidiaries of national banks enjoyed the same immunity from state visitation" as national banks possessed, and Cuomo reiterated that Watters "addresses and answers no other question."49

Cuomo's emphatic pronouncement concerning the narrow scope of Watters echoed statements made by Justice Ginsburg during the oral argument in Cuomo. Justice Ginsburg wrote the majority opinion supporting the OCC's position in Watters, but she joined the majority opinion striking down the OCC's regulation in Cuomo. During oral argument in Cuomo, Justice Ginsburg advised counsel for the Clearing House that " $[\mathrm{t}]$ he sole question [in Watters] was whether ... the national bank's operating subsidiary was to be equated with a division of the national bank. That was the only question provided the Court." ${ }^{50}$ She also admonished counsel that "I do not think that excerpts from [the Watters] opinion should be taken out of that context." $" 51$

${ }^{46} I d$. at 2718 .

${ }^{47} I d$. at $2718-19$.

48 Id. at 2719.

49 Id. at 2717.

50 Transcript of Oral Argument in Cuomo, at 37 (statement by Justice Ginsburg to Seth P. Waxman, counsel for the Clearing House), available at http://www.supremecourtus.gov/oral_arguments/argument_tran scripts/08-453.pdf.

${ }^{51}$ Id. at 38 (same). 
The majority opinion in Cuomo and Justice Ginsburg's comments at oral argument appear to have been consciously designed to limit the precedential force of Watters in future cases raising preemption issues under the NBA. The Cuomo majority might have been concerned about certain statements in Watters that indicated an expansive view of the NBA's preemptive effect. ${ }^{52}$ Not surprisingly, the Clearing House quoted those statements in its brief in Cuomo. ${ }^{53}$ During oral argument in Cuomo, Justice Ginsburg stated that she viewed the Clearing House's discussion of Watters in its brief as "an inaccurate description of what that opinion held." 54 During oral argument, Justice Souter similarly questioned the OCC's assertion that a 1994 statute, 12 U.S.C. § 36(f)(1)(B), granted the OCC exclusive authority to enforce state laws against interstate branches of national banks. Justice Souter suggested that the text and legislative history of the 1994 statute did not clearly manifest a congressional purpose to bar state officials from enforcing valid, non-preempted state laws against interstate branches of national banks. If Congress had plainly stated that intent, Justice Souter said that he would have expected such an "extraordinary" displacement of state enforcement authority to produce "rather a dust-up." The fact that Section 36(f)(1)(B) failed to trigger any substantial controversy created what Justice Souter described as "kind of a 'dog that didn't bark' argument" and, therefore, led him to doubt the OCC's exclusivity claim. ${ }^{55}$

52 See Watters, 550 U.S. at 11 ("federal control [under the NBA] shields national banking from unduly burdensome and duplicative state regulation"); $i d$. at 13 ("state law may not significantly burden a national bank's own exercise of its real estate lending powers, just as it may not curtail or hinder a national bank's efficient exercise of any other power, incidental or enumerated under the NBA").

${ }^{53}$ See Brief of Respondent Clearing House Ass'n in Cuomo, at 29 \& n.5 (quoting Watters, 550 U.S. at 11, $13)$.

${ }^{54}$ Transcript of Oral Argument in Cuomo, supra note 50, at 37 (statement by Justice Ginsburg to Mr. Waxman).

${ }_{55}$ Id. at 31-32 (colloquy between Justice Souter and Malcolm L. Stewart, counsel for the OCC). Section 36(f)(1)(B) provides that four specific categories of state laws applicable to interstate branches of national banks "shall be enforced" by the OCC. 12 U.S.C. §36(f)(1)(B). The OCC argued that the words "shall be enforced" were intended to give the OCC exclusive power to enforce those state laws against national bank branches. Id. at 25-26 (argument of Mr. Stewart). NYAG Cuomo contended that the purpose of the clause was to direct the OCC to exercise its concurrent authority to enforce applicable state laws against national bank branches, because Congress believed that the OCC was improperly ignoring those laws. Id. at 13 (argument of Barbara D. Underwood, counsel for Mr. Cuomo). The majority opinion in Cuomo concluded that the terms of Section 36(f)(1)(B) "shed no light on the meaning of 'visitorial powers' in the National Bank Act, a statute that it does not refer to and that was enacted more than a century earlier." Cuomo, 129 S. Ct. at 2718 n.3. In contrast, the dissenting opinion in Cuomo maintained that Section 36(f)(1)(B) 
Justice Ginsburg also indicated her apprehension about the potentially far-reaching scope of the OCC's claim of exclusive enforcement authority over national banks. During the oral argument in Cuomo, she asked counsel for the Clearing House whether the OCC's exclusivity claim applied not only to "core banking activities" but also to "matters incidental to banking." 56 Counsel responded that the OCC's exclusivity claim "would [apply] if those incidental authorities are in fact authorized, approved and regulated by the OCC." 57

Justice Ginsburg's inquiry was apparently prompted by her concern that the OCC might assert exclusive enforcement authority over the full range of national bank activities that the OCC deemed to fall within the "incidental powers . . necessary to carry on the business of banking" under 12 U.S.C. $§ 24$ (Seventh). Justice Ginsburg wrote the Supreme Court's 1995 decision in NationsBank of N.C., N.A. v. Variable Annuity Life Ins. Co. (VALIC). ${ }^{58}$ In VALIC, the Court held that an OCC opinion letter, which approved a bank activity as falling within the "incidental powers" of national banks, was entitled to judicial deference under Chevron. ${ }^{59}$ However, the Court cautioned the OCC that "[ $[\mathrm{t}]$ he exercise of the [agency's] discretion . . . must be kept within reasonable bounds" and should not include "[v]entures distant from dealing in financial investment instruments." ${ }^{, 0}$ Amicus briefs filed in Cuomo by a realtors' association and by consumer groups informed the Court that, notwithstanding the cautionary language in VALIC, the OCC had expansively construed the "incidental powers" of national banks. For example, the OCC issued rulings that approved such far-flung activities as "providing counseling to Medicare and Medicaid recipients, selling long-term care and disability insurance, operating roadside assistance programs, finding customers for automobile sales, developing commercial buildings

\footnotetext{
"reinforces OCC's interpretation of $\S$ 484(a)." Id. at 2728 n.2. (Thomas, J., dissenting in part).

56 Transcript of Oral Argument in Cuomo, supra note 50, at 48 (question by Justice Ginsburg to Mr. Waxman).

${ }^{57} I d$. (statement by Mr. Waxman). Counsel added that "this case doesn't require [the Court] to address" the issue of incidental activities, because Cuomo involved real estate lending, "an express power [of national banks] under [12 U.S.C.] section 371(a)." Id. at 48-49.

58513 U.S. 251 (1995) ("VALIC").

${ }^{59} \mathrm{Id}$. at 257.

${ }^{60} I d$. at 259 n. 2 .
} 
and managing residential condominiums in those buildings, dispensing various prepaid products ... through their ATM machines, operating a 'virtual mall' where bank customers 'can shop for a range of financial and non-financial products and services,' and providing 'Web design and development services.' ${ }^{, 61}$

As the consumer groups' brief pointed out, the OCC had published a compilation of national bank powers in which the OCC declared that " $[\mathrm{t}]$ he business of banking is an evolving concept and the permissible activities of national banks similarly evolve over time." ${ }^{92}$ At oral argument in Cuomo, Justice Ginsburg noted that "today national banks have a lot of . . . authority to do things incidental to banking." ${ }^{93}$ Justice Ginsburg evidently understood that the OCC was continually expanding the scope of "incidental powers" for national banks under the NBA.

Thus, comments by Justice Ginsburg and Justice Souter during oral argument in Cuomo foreshadowed their shift from a pro-OCC position in Watters to an anti-OCC position in Cuomo. Justice Breyer was the only member of the Cuomo majority who did not indicate any doubts about the OCC's position during the oral argument. Like Justice Ginsburg and Justice Souter, Justice Breyer supported the OCC in Watters. In addition, Justice Breyer expressed misgivings during oral argument in Cuomo about the potential disadvantages of allowing state attorneys general to second-guess the enforcement decisions of the OCC. ${ }^{64}$ His decision to join the majority opinion in Cuomo was therefore somewhat surprising.

\footnotetext{
${ }^{61}$ Brief of Amicus Curiae Nat'1 Ass'n of Realtors in Support of Petitioner in Cuomo, at at 17-18 (citing and quoting OCC, Activities Permissible for a National Bank, 2007 (2008)); see also Brief of Amici Curiae Center for Responsible Lending et al. in Support of Petitioner in Cuomo, at 12 (same).

62 Brief of Amici Curiae Center for Responsible Lending et al., supra note 61, at 13 (quoting OCC, Activities Permissible for a National Bank, 2007, at 1 (2008)). Similarly, the OCC's Chief Counsel and Assistant Chief Counsel proclaimed in a 1997 article that "the business of banking is in a constant state of evolution." Julie L. Williams \& James F.E. Gillespie, Jr., "The Business of Banking: Looking to the Future-Part II," 52 Business Lawyer 1279, 1299 (1997). They further contended that OCC decisions defining the "incidental powers" of national banks "provide key authority for national banks to transform their banking franchises in ways that will be necessary to enable them to compete and effectively serve customers in the financial arena of the future." Id. at 1331.

${ }_{63}$ Transcript of Oral Argument in Cuomo, supra note 50, at 48 (statement by Justice Ginsburg).

${ }^{64}$ Id. at 6-11 (colloquies between Justice Breyer and Barbara D. Underwood, counsel for Mr. Cuomo).
} 
The majority opinion in Cuomo criticized the OCC for adopting an aggressive theory of preemption that "attempts to do what Congress declined to do: exempt national banks from all state banking laws, or at least state enforcement of those laws." ${ }^{65}$ In view of the virtually unbounded theories of "incidental powers" and preemption advanced by the OCC, the Cuomo majority may have decided to include in Cuomo a narrowly circumscribed reading of Watters in order to curtail the OCC's ability to assert similar preemption claims in the future. As discussed in the next section of this chapter, it also seems likely that the Cuomo majority was responding to the subprime financial crisis and federal bailouts of several leading national banks. Those developments may have caused the majority to lose confidence in the OCC's policy judgments, particularly with regard to the desirability of preempting state enforcement of mortgage lending laws, an issue that was central to both Watters and Cuomo.

In sharp contrast to the broad preemptive language used by the Court in Watters, the majority opinion in Cuomo indicated a renewed appreciation for federalism and the potentially beneficial effects of a supplemental state role in regulating financial institutions. Justice Scalia pointed out that "[n]o one denies that the [NBA] leaves in place some state substantive law affecting banks." ${ }^{66}$ He further observed that "States . . have always enforced their general laws against national banks - and have enforced their banking-related laws against national banks for at least 85 years, as evidenced by St. Louis." ${ }^{67}$ The foregoing statements in Cuomo are consistent with the Supreme Court's 1997 decision in Atherton v. FDIC, ${ }^{68}$ where the Court declared that "federally chartered banks are subject to state law." ${ }^{69}$ As support for that principle, Atherton quoted decisions reaching back to an 1870 case - decided only six years after the NBA's enactment - where the Court held that national banks

${ }^{65}$ Cuomo, 129 S. Ct. at 2720.

${ }^{66} I d$. at $2717-18$.

${ }^{67} \mathrm{Id}$. at 2720.

${ }_{68} 519$ U.S. 213 (1997).

${ }^{69} I d$. at 222. 
are subject to the laws of the State, and are governed in their daily course of business far more by the laws of the State than of the nation. All their contracts are governed and construed by State laws. Their acquisition and transfer of property, their right to collect their debts, and their liability to be sued for debts, are all based on State law. It is only when State law incapacitates the [national] banks from discharging their duties to the federal government that it becomes unconstitutional. ${ }^{70}$

In St. Louis, the Supreme Court explained that "the operation of general state laws upon the dealings and contracts of national banks" is the "rule," while preemption is an "exception" that applies only when state laws "expressly conflict with the laws of the United States or frustrate the purpose for which national banks were created, or impair their efficiency to discharge the duties imposed upon them by the law of the United States." ${ }^{\text {71 }}$ Similarly, in Anderson National Bank v. Luckett ${ }^{72}$ the Court held that "national banks are subject to state laws, unless those laws infringe the national banking laws or impose an undue burden on the performance of the banks' functions." ${ }^{73}$ In Cuomo, the Court cited St. Louis and Luckett with approval, ${ }^{74}$ and both decisions therefore retain strong precedential value with respect to future preemption cases under the NBA.

In Lewis v. Fidelity \& Deposit Co., ${ }^{75}$ the Court held that the NBA embodies a congressional "policy of equalization" between the national and state banking systems. ${ }^{76}$ Congress has long sought to preserve the vitality of the dual banking system by maintaining a basic parity of competitive opportunities between state and national banks. ${ }^{77}$ This congressional policy of equalization has been carried out in two ways - first, by “expressly incorporat[ing] state-law standards into several federal statutes," and second, "through statutory silence [that]

70 Id. at 222-23 (quoting National Bank v. Commonwealth, 76 U.S. (9 Wall.) 353, 362 (1870)). In a 1996 decision, the Supreme Court similarly held that "States [retain] the power to regulate national banks, where ... doing so does not prevent or significantly interfere with the national bank's exercise of its powers." Barnett Bank of Marion County, N.A. v. Nelson, 517 U.S. 25, 33 (1996).

71 St. Louis, 263 U.S. at 656 (quoting McClellan v. Chipman, 164 U.S. 347, 357 (1896)).

72321 U.S. 233 (1944).

${ }^{73} I d$. at 248.

${ }^{74}$ See Cuomo, 129 S. Ct. at 2717, 2718, 2720-21.

75292 U.S. 559 (1934).

${ }^{76} \mathrm{Id}$. at 564-65.

${ }^{77}$ See Wilmarth, supra note 12, at 253-65. 
permits state laws to govern other aspects of the operations of national banks except in situations where a state law creates an irreconcilable conflict with federal law." ${ }^{78}$ Cuomo did not cite Lewis, but Justice Stevens quoted Lewis with approval in his dissenting opinion in Watters. ${ }^{79}$

The Cuomo majority held that the $\mathrm{OCC}$ erred in asserting that "the State may not enforce its valid, non-preempted laws against national banks. The bark remains, but the bite does not." The Cuomo majority described this result as “[b]izarre," particularly in view of the Court's statement in St. Louis that it would be a "fallacy" to acknowledge "the binding quality of a statute but deny the power of enforcement." ${ }^{81}$ Indeed, St. Louis declared that the "power [of enforcement] is essentially inherent in the very conception of law." 82

During oral argument in Cuomo, Justice Ginsburg similarly found it "passing strange" for the OCC to maintain that "State ... substantive law [is] applicable to [national] banks but only the Federal authority can enforce it." ${ }^{\prime 3}$ Justice Ginsburg asked counsel for the OCC if there were any comparable federal statutes in which Congress recognized the applicability of state laws but gave federal officials exclusive authority to enforce those laws. Counsel was unable to identify any such federal statute. ${ }^{84}$

In contrast to the "[b]izarre" outcome created by the OCC's regulation, Justice Scalia maintained that an "entirely commonplace result" would be produced by interpreting $\S 484($ a) as “[c]hanneling state attorneys general into judicial law enforcement proceedings ... [while] preserv[ing] a regime of exclusive administrative oversight by the [OCC]." ${ }^{85}$ Justice Scalia explained that such an outcome "echoes many other mixed state/federal regimes in which the Federal Government exercises general oversight while leaving state substantive law in place."

${ }^{78} I d$. at 266. See Lewis, 292 U.S. at 564-65, 566 (describing both methods for applying state laws to national banks).

${ }^{79}$ Watters, 550 U.S. at 25 (Stevens, J., dissenting, joined by Roberts, C.J., and Scalia, J.).

${ }^{80}$ Cuomo, 129 S. Ct.. at 2718.

${ }^{81}$ Id. at 2718 (quoting St. Louis, 263 U.S. at 660).

82 St. Louis, 263 U.S. at 660, quoted in Cuomo, 129 S. Ct. at 2718.

83 Transcript of Oral Argument in Cuomo, supra note 50, at 27.

${ }^{84}$ Id. at 27-28 (colloquy among Justice Ginsburg, Malcolm L. Stewart and Justice Scalia).

${ }^{85}$ Cuomo, 129 S. Ct. at 2718.

${ }^{86} I d$. 
In this regard, the Cuomo majority cited the Court's recent decision in Wyeth v. Levine, ${ }^{87}$

discussed below, in which the Court held that the federal statutory regime governing labeling of prescription drugs did not preempt failure-to-warn claims based on state tort law. Thus, in marked contrast to Watters, the majority opinion in Cuomo interpreted the NBA in light of the strong federalism principles applied in cases such as St. Louis, Lewis, Luckett, Atherton and Wyeth.

\section{The Impact of the Subprime Financial Crisis and the OCC's Weak Record of Enforcing Consumer Protection Laws}

The outbreak of the subprime financial crisis in August 2007 and subsequent federal bailouts of several leading national banks apparently changed the Supreme Court's assessment of the desirability of OCC preemption between the dates of the Court's decisions in Watters (April 17, 2007) and Cuomo (June 29, 2009). Amicus briefs filed in support of NYAG Cuomo contained numerous references to the financial crisis. In addition, those briefs sharply attacked the OCC for its sweeping preemption of state law and its alleged failure to protect consumers from predatory lending. Although the majority opinion in Cuomo did not directly refer to the financial crisis, other evidence indicates that the Court was aware of the crisis and the controversy surrounding the OCC's preemption efforts.

\section{Criticisms of the OCC's Preemptive Actions and Supervisory Record}

Amicus briefs filed in support of NYAG Cuomo strongly criticized the OCC for (i) failing to protect consumers against abusive mortgage lending practices by national banks and (ii) preempting the states' efforts to protect consumers. Amici-who included members of Congress, state officials, civil rights organizations and consumer groups - contended that the OCC's preemptive actions and supervisory failures were a significant factor leading to the subprime financial crisis. ${ }^{88}$

87129 S. Ct. 1187 (2009)

${ }^{88}$ See, e.g., the following amicus briefs filed in Cuomo to support NYAG Cuomo: Brief of Members of Congress as Amici Curiae in Support of Petitioner, at 3-8 (filed by six members of Congress, including Rep. Barney Frank); Brief for the States of North Carolina et al. as Amici Curiae in Support of Petitioner, at 8-14, 22-25, 33-39 (filed by the attorneys general of 49 states and the District of Columbia); Brief of the 
As amici pointed out, the OCC issued a series of preemptive rules and orders that barred the states from enforcing a wide range of state laws - including state anti-predatory lending laws and other consumer protection laws - against national banks and their operating subsidiaries. ${ }^{89}$ The OCC's rulings had the cumulative effect of "cancel[ing] out much state-level consumer protection law." 90

Amici cited studies showing that the OCC had powerful budgetary incentives to use preemption as a marketing tool to persuade the largest banks to operate under national charters. The OCC's budget is funded almost entirely by assessments paid by national banks, and the biggest banks pay the highest assessments. ${ }^{91}$ A former head of the OCC described preemption as "a significant benefit of the national [bank] charter - a benefit that the OCC has fought hard over the years to preserve." ${ }^{92}$ In response to the OCC's preemption campaign, several large, multistate banks converted from state to national charters, thereby producing a significant increase in the OCC's assessment revenues. ${ }^{93}$

American Ass'n of Residential Mortgage Regulators as Amicus Curiae in Support of Petitioner, at 1-2, 1721 (filed by an organization of state officials who regulate mortgage lenders, servicers and brokers); Brief of the Conference of State Bank Supervisors as Amicus Curiae in Support of Petitioner, at 3-4, 17-21, 28-32 (filed by an organization of state officials who regulate state-chartered banks); Brief of Lawyers' Committee for Civil Rights under Law et al. as Amici Curiae in Support of Petitioner, at 1-4, 20-22, 26-38 (brief filed by three civil rights groups); Brief Amici Curiae of Center for Responsible Lending et al., supra note 61 (amicus brief filed by nine consumer groups and New York City's Department of Consumer Affairs)..

${ }^{89}$ See, e.g.., 66 Fed. Reg. 28,593 (2001) (order declaring that Michigan laws, which required car dealers to obtain lending licenses and comply with Michigan consumer protection laws if they arranged auto loans, were preempted by the NBA with respect to car dealers who acted as agents of national banks in arranging auto loans); 66 Federal Register 34,784 (2001) (adopting 12 C.F.R. $\$ 7.4006$, which preempted the application of state laws to operating subsidiaries of national banks); 68 Federal Register 46,264 (2003) (preemption determination declaring that the Georgia Fair Lending Act was completely preempted by federal law as to national banks and their operating subsidiaries); 69 Federal Register 1904 (2004) (adopting 12 C.F.R. $\S \S 7.4007-7.4009$ and 34.4, which preempted all state laws that "obstruct, impair, or condition a national bank's ability to fully exercise its Federally authorized powers" in four broadly-defined areas - real estate lending, lending not secured by real estate, deposit-taking, and other "operations").

${ }^{90}$ Oren Bar-Gill \& Elizabeth Warren, "Making Credit Safer," 157 University of Pennsylvania Law Review $1,82(2008)$.

${ }_{91}$ Id. at 93-94; W ilmarth, supra note 12 , at 276.

92 Speech by Comptroller of the Currency John D. Hawke, Jr., Feb. 12, 2002, quoted in Wilmarth, supra note 12 , at $236,274$.

93 Bar-Gill \& Warren, supra note 90, at 81-83, 93-94 (citing charter conversions by three large banks in 2004 and 2005, which moved \$1 trillion of assets from the state banking system to the national banking system and produced a 15\% increase in the OCC's budget); Wilmarth, supra note 12, at 233-36, 274-79, 289-93. 
In addition, studies cited by amici described the OCC's record of enforcing consumer protection laws as a "long history of inaction," "relatively lax," "weak" and "unimpressive." Publicly available information indicated that, during 1995-2007, the OCC issued only 13 public enforcement orders against national banks for violations of consumer protection laws. ${ }^{95}$ Most of those enforcement orders were issued against small national banks, and only one order included a charge that the bank violated state laws. ${ }^{96}$ In that one case, the OCC took action only after the public became aware that a California prosecutor was investigating the offending bank. ${ }^{97}$

The states' record of protecting consumers presented a dramatic contrast with the OCC. Between 1999 and 2006, more than thirty states enacted laws to combat predatory lending. ${ }^{98}$ A recent study found that state anti-predatory laws reduced the number of mortgages with unsound or abusive features such as prepayment penalties, balloon payments, and no- and lowdocumentation terms. ${ }^{99}$ In addition, state officials vigorously used their enforcement powers to prosecute financial service providers for a wide range of unlawful practices. ${ }^{100}$ In 2003 alone, "state bank supervisory agencies performed more than 20,000 investigations in response to

\footnotetext{
94 Bar-Gill \& Warren, supra note 90, at 90-95 (quote at 94); Christopher L. Peterson, "Federalism and Predatory Lending: Unmasking the Deregulatory Agenda," 78 Temple Law Review 1, 70-74, 77-81 (2005) (quote at 81); Amy Quester \& Kathleen Keest, "Looking Ahead After Watters v. Wachovia Bank: Challenges for the Lower Courts, Congress, and the Comptroller of the Currency," 27 Review of Banking \& Financial Law 187, 195-97 (2008) (quote at 195); Wilmarth, supra note 12, at 232 (quote), 274-77, 289-93, 310-16, 351-56.

95 See Bar-Gill \& Warren, supra note 90, at 92-93; W ilmarth, supra note 12, at 353, 355-56; Stephanie Mencimer, "No Account," New Republic, Aug. 27, 2007, at 14.

${ }^{96}$ In re Providian National Bank, June 28, 2000, 2000 OCC Enf. Dec. LEXIS 55, at*1 (alleging violations of California statutes prohibiting unfair business practices); see also Wilmarth, supra note 12, at 353-56. 97 Wilmarth, supra note 12, at 316 \& n.357; "Correspondence," New Republic, Oct. 8, 2007, at 7 (response by Stephanie Mencimer to letter from Comptroller of the Currency John C. Dugan).

${ }_{98}$ Julia Patterson Forrester, "Still Mortgaging the American Dream: Predatory Lending, Preemption, and Federally Supported Lenders," 74 University of Cincinnati Law Review 1303, 1308-10, 1319-22, 1359-68 (2006); Patricia A. McCoy et al., "Systemic Risk Through Securitization: The Result of Deregulation and Regulatory Failure," 41 Connecticut Law Review 1327, 1348 (2009).

99 Raphael W. Bostic et al., "Mortgage Product Substitution and State Anti-Predatory Lending Laws: Better Loans and Better Borrowers?" (May 12, 2009), Univ. of Pa. Instit. for Law \& Econ. Res. Paper 09-27, at 19-24, available at $\mathrm{http}: / / \mathrm{ssrn} . \mathrm{com} / \mathrm{abstract}=1460871$.

100 Wilmarth, supra note 12, at 316, 348-52, 354-55; Amir Efrati \& Aaron Lucchetti, "U.S. News: Cuomo Blazes Own Trail as Wall Street Cop," Wall Street. Journal, Aug. 11, 2008, at A3; Brooke Masters, "In Spitzer's footsteps: Cuomo trains his sights on financial services," Financial Times, June 5, 2007 , at 1.
} 
consumer complaints about abusive lending practices, and those investigations produced more than 4,000 enforcement actions."

Despite these initiatives by the states, the OCC's actions seriously obstructed the states' ability to protect consumers from predatory lending practices. In addition to adopting preemptive regulations, the OCC filed amicus briefs in many other cases to support efforts by national banks to obtain judicial decisions preempting state consumer protection laws. The OCC's decision to sue NYAG Spitzer, in concert with the Clearing House (whose members included most of the largest national banks), provided a striking example of the OCC's unrelenting efforts to support its regulated constituents and to block efforts by state officials to enforce state laws against those constituents. $^{102}$

By preempting state laws and state enforcement proceedings, the OCC (i) undermined the effectiveness of state predatory lending laws, ${ }^{103}$ and (ii) contributed to the severity of the current credit crisis by "stifling . . prescient state enforcers and legislators" who tried to prevent irresponsible lending. ${ }^{104}$ For example, the OCC issued rulings declaring that Georgia officials were preempted from applying the Georgia Fair Lending Act not only to national banks and their operating subsidiaries, but also to mortgage brokers who arranged loans funded at closing by national banks or their subsidiaries. ${ }^{105}$ Similarly, after state officials brought enforcement actions

101 Wilmarth, supra note 12, at 316 (quoting 2004 House budget committee document); see also Eric Nalder, "Mortgage System Crumbled While Regulators Jousted," Seattle Post-Intelligencer, Oct. 11, 2008, at A1 (reporting that "States ... took 3,694 enforcement actions against mortgage lenders and brokers in 2006 alone, according to congressional testimony").

102 Bar-Gill \& Warren, supra note 90, at 91; Quester \& Keest, supra note 94, at 199; Wilmarth, supra note 12, at 289-93, 353-55; Mencimer, supra note 95 (citing an informal survey indicating that the OCC filed 60 amicus briefs in court cases from 1994 to 2006, "at least 58 of which were in support of [national] banks"); supra notes 6-13 and accompanying text (discussing the decision by the OCC and the Clearing House to sue Mr. Spitzer).

103 Bar-Gill \& Warren, supra note 90, at 81-82, 90-95; Forrester, supra note 98, at 1339-42, 1349-53; Quester \& Keest, supra note 94, at 223-37; Wilmarth, supra note 12, at 306-16, 348-52.

104 Robert Berner \& Brian Grow, "They Warned Us: The Watchdogs Who Saw the Subprime Disaster Coming - and How They Were Thwarted by the Banks and Washington," Business Week, Oct. 20, 2008, at 36, 38; see also Nicholas Bagley, "Subprime Safeguards We Needed," Washington Post, Jan. 25, 2008, at A19; Nalder, supra note 101.

${ }^{105}$ OCC Preemption Determination and Order, 68 Fed. Reg. 46,264 (Aug. 5, 2003); OCC Interpretive Letter No. 1002, May 13, 2004, from Comptroller of the Currency John D. Hawke, Jr. to Georgia Banking Commissioner David G. Sorrell. 
and imposed heavy penalties against two major nonbank mortgage lenders (Household and Ameriquest), those organizations sold themselves to large national banks (HSBC and Citigroup) and thereby obtained substantial protection from further state regulation. A comparable incident occurred in 2006, when the Iow a Division of Banking sued Okoboji Mortgage for refusing to cooperate with the state's investigation of suspected illegal lending practices. Okoboji promptly sold itself to a large national bank (Wells Fargo) and then claimed immunity from any further state enforcement proceedings. ${ }^{106}$

The OCC's preemption rules closely paralleled regulations that the Office of Thrift Supervision ("OTS") issued between 1983 and 1996. The OTS regulations preempted a broad range of state laws from applying to federal thrifts and their operating subsidiaries. Like the OCC, the OTS issued additional rulings that specifically preempted the application of state predatory lending laws to federal thrifts and their subsidiaries and agents. Again like the OCC, the OTS has strong financial incentives to use preemption as a means of attracting large, multistate institutions to its chartering regime, because virtually all of the OTS's budget is financed by assessments and fees paid by federal thrifts. Given those incentives, it is not surprising that the OTS's record of initiating public enforcement actions against its regulated constituents for violating consumer protection laws is as sparse as the OCC's score sheet. ${ }^{107}$

The preemptive actions of the OCC and OTS prevented state officials from responding to predatory lending problems with the same effectiveness they displayed in exposing a series of

106 Brief of North Carolina et al. in Cuomo, supra note 88, at 11-12; Erick Portanger et al., "Buying American: HSBC to Acquire Lender in Big Bet on U.S. Economy," Wall Street Journal, Nov. 15, 2002, at A1; Harry Terris, "Citi-ACC: A Bet Vertical Integration Still Has Legs," American Banker, Sept. 13, 2007, at 1; Berner \& Grow, supra note 104, at 41-42 (describing incident involving Okoboji Mortgage).

107 Wilmarth, supra note 12, at 228, 233-35, 280-87 (discussing the OTS' preemption initiatives, and their similarity to the OCC's preemptive actions); State Farm Bank, FSB v. Reardon, 539 F.3d 336 (2008) (upholding an OTS ruling that permitted agents of a federal thrift to offer mortgage loans in Ohio without complying with Ohio's laws governing mortgage brokers); Office of Thrift Supervision, Annual Report, Fiscal Year 2008, at 43, available at http://files.ots.treas.gov/482008.pdf (showing that 95\% of the OTS' budget is funded by assessments and fees paid by federal thrifts). For discussions of the OTS' weak record of enforcing consumer protection laws against federal thrifts, see McCoy, supra note 98, at 1348-57; Nalder, supra note 101 (reporting that the OTS initiated only "five to six" enforcement actions against federal thrifts for unfair and deceptive practices between 2000 and 2008). 
scandals on Wall Street between 2002 and 2006. State authorities took the lead in prosecuting securities firms (including securities affiliates of major banks) for pressuring their research analysts to produce biased reports to investors, for engaging in corrupt practices related to initial public offerings, and for permitting hedge funds to carry out abusive market timing and late trading strategies that exploited mutual funds sponsored by securities firms. The Securities and Exchange Commission (SEC) cooperated with the states' enforcement measures against Wall Street firms. ${ }^{108}$ In contrast, as shown above, the OCC and OTS repeatedly issued preemptive rulings and intervened in lawsuits to block efforts by state officials to enforce state anti-predatory lending laws against federally-chartered depository institutions and their subsidiaries and agents.

The Supreme Court was evidently aware of the public controversy over the OCC's aggressive preemptive actions and its questionable commitment to protecting consumers when the Court considered both Watters and Cuomo. As indicated above, remarks by Justices Ginsburg and Souter at the Cuomo oral argument indicated that they had serious misgivings about the OCC's far-reaching assertions of preemptive authority. ${ }^{109}$ In addition, at the oral arguments in both Watters and Cuomo, Justice Stevens asked pointed questions about the number of personnel that the OCC assigned to its enforcement and compliance functions. Those questions suggested that Justice Stevens had significant doubts about the OCC's commitment to consumer protection. $^{110}$

In addition, Justice Stevens' dissenting opinion in Watters strongly criticized the Court for upholding an OCC regulation, 12 C.F.R. $\S 7.4006$, that barred the states from regulating statechartered mortgage lending companies that were operating subsidiaries of national banks. Justice

\footnotetext{
108 Wilmarth, supra note 12, at 348-52; Arthur E. Wilmarth, Jr., "The Dark Side of Universal Banking: Financial Conglomerates and the Origins of the Subprime Lending Crisis," 41 Connecticut Law Review 963, 1000-02 (2009), available at $\mathrm{http}: / / \mathrm{ssrn} . \mathrm{com} / \mathrm{abstract}=1403973$.

109 See supra notes 50-63 and accompanying text.

110 Transcript of Oral Argument in Watters v. Wachovia Bank, N.A., at 45-46 (colloquy between Justice Stevens and Sri Srinivasan, counsel for the United States), available at http://www.supremecourtus.gov/oral_arguments/argument_transcripts/05-1342.pdf; Transcript of Oral Argument in Cuomo, supra 50, at 25-26 (colloquy between Justice Stevens and Malcolm L. Stewart, counsel for the OCC).
} 
Stevens declared that "[i]t is especially troubling that the Court so blithely preempts Michigan laws designed to protect consumers. Consumer protection is quintessentially a 'field which the States have traditionally occupied.",111 In addition, Justice Stevens warned that "the OCC's regulation may drive companies seeking refuge from state regulation into the arms of federal parents, harm those state competitors who are not lucky enough to find a federal benefactor, and hamstring States' ability to regulate the affairs of state corporations." 112

\section{The OCC's Unfounded Attack on the States}

In response to the strong attacks on its preemptive actions and its consumer protection record, the OCC attempted to shift the blame for the subprime mortgage debacle to the states. In Cuomo, six former Comptrollers of the Currency filed an amicus brief in support of the OCC and the Clearing House. The former Comptrollers alleged that (i) nonbank mortgage lenders and brokers bore most of the blame for the subprime financial crisis, and (ii) nonbank lenders and brokers "are - and always have been - subject to the oversight and enforcement jurisdiction of state officials." The former Comptrollers further claimed that "the OCC provided early and unmatched leadership on subprime lending." in March 2009, the incumbent Comptroller of the Currency declared that nonbank lenders and brokers "have been widely recognized as the overwhelming source of abusive subprime mortgages." He also contended that "national banks were not significant originators of subprime loans." 114

\footnotetext{
111 Watters, 550 U.S. at 35-36 (Stevens, J., dissenting) (quoting Rice v. Santa Fe Elevator Corp., 330 U.S. 218, 230 (1947)). Chief Justice Roberts and Justice Scalia joined the dissenting opinion in Watters. Justice Stevens and Justice Scalia were members of the majority in Cuomo. However, as discussed infra in note 136, Chief Justice Roberts joined the dissenting opinion in Cuomo.

112 Id. at 43 .

113 Brief of All Former Comptrollers of the Currency since 1973 as Amici Curiae in Support of Respondents in Cuomo, at 32-34 (quotes at 34).

114 Testimony of Comptroller of the Currency John C. Dugan before the House Committee on Financial Services, Mar. 20, 2009, at 15, available at http:/www.occ.treas.gov/ftp/release/2009-26a.pdf. Mr. Dugan's testimony was cited in the amicus brief filed in Cuomo by six former Comptrollers of the Currency. Brief of All Former Comptrollers of the Currency since 1973, supra note 113, at 32-33.
} 
The OCC's attempt to blame the states for the current financial crisis is unpersuasive.

Nonbank lenders and brokers did play a significant role in originating subprime and Alt-A mortgages. However, as discussed above, the OCC and OTS barred the states from regulating nonbank lenders and brokers that were affiliated with national banks. In addition, national banks and federal thrifts acquired several of the largest nonbank mortgage lenders between 1999 and 2007. For example, HSBC bought Household, Citigroup purchased Associates First Capital and Argent (the parent of Ameriquest), Washington Mutual (Wamu) bought Long Beach Mortgage and National City purchased First Franklin. ${ }^{115}$

A recent Federal Reserve study found that depository institutions (together with their subsidiaries and other affiliates) accounted for about half of nonprime (subprime and Alt-A) mortgages originated in 2004 and 2005, 54 percent of nonprime mortgages in 2006, and 79 percent of nonprime mortgages in 2007. ${ }^{116}$ This accelerating shift in nonprime loan originations toward national banks and federal thrifts and their affiliates reflected the growing impact of the OCC's and OTS' preemption rules. Those preemption rules shielded federally-chartered institutions and their operating subsidiaries from state predatory lending laws, while unaffiliated nonbank lenders remained subject to state laws. ${ }^{117}$

A study by the National Consumer Law Center found that national banks, federal thrifts and their operating subsidiaries accounted for $31.5 \%$ of subprime mortgage loans, $40.1 \%$ of AltA loans, and $51.0 \%$ of payment-option and interest-only adjustable-rate mortgages (ARMs) originated in 2006. ${ }^{118}$ A second study, by the Center for Public Integrity, confirmed that large

115 Wilmarth, supra note 108, at 1013-15, 1017-18; see also supra note 106 and accompanying text.

116 Robert B. Avery et al., "The 2007 HMD A Data," Federal Reserve Bulletin., Dec. 2008, at A107, $124-$ 25,124 (tbl. 11) (showing percentages of "[h]igher-priced loans" made in each year by depository institutions and their subsidiaries and other affiliates, and by independent mortgage companies); see also id. at A107 n.7 (explaining that the "higher-priced loans" covered by the study generally fell into the subprime and Alt-A categories).

117 McCoy et al., supra note 98, at 1348-55; Wilmarth, supra note 108, at 1013-19.

118 National Consumer Law Center (NCLC), "Preemption and Regulatory Reform: Restore the States' Traditional Role as 'First Responder," Sept. 2009, at 11-13 \& tbls. 1-3, available at http://www.nclc.org/issues/le gislative/content/PR-Preemption091609.pdf (last visited on Sept. 28, 2009). The NCLC's study showed that, in 2006, national banks and their operating subsidiaries accounted for $19.2 \%$ of subprime loans, $11.3 \%$ of Alt-A loans and $31.2 \%$ of payment-option and interest-only ARMs. Id. 
national banks and federal thrifts (along with their affiliates) ranked among the biggest funding sources for subprime mortgages between 2005 and 2007. The largest subprime lender during that period was Countrywide. Countrywide operated as a national bank from 2001 to 2007 and as a federal thrift from 2007 to 2008 , at which point it was forced - on the brink of insolvency - to enter into an emergency merger with Bank of America (BofA). ${ }^{119}$

In addition to Countrywide, the top 25 sources of funding for subprime mortgages between 2005 and 2007 included seven big national banks (Citigroup, JP Morgan Chase, HSBC, Wachovia, Wells Fargo, National City and Capital One), two large federal thrifts (Wamu and IndyMac), three major Wall Street firms, which each controlled a federal thrift (Merrill Lynch, Lehman Brothers and Bear Stearns), and a big insurance company that also controlled a federal thrift (American International Group (AIG)). ${ }^{120}$ Those three Wall Street firms and AIG were subject to consolidated supervision by the OTS because of their ownership of federal thrifts. ${ }^{121}$ Many of the same financial institutions were heavily involved in Alt-A lending, as was BofA. Alt-A mortgages included some of the most risky loans, including low- and nodocumentation mortgages (frequently called "liars' loans") and payment option ARMs. ${ }^{122}$ In 119 Paul Muolo \& Mathew Padilla, Chain of Blame: How Wall Street Caused the Mortgage and Credit Crisis 18-2 1, 111-25, 249-70, 300-03 (Hoboken, NJ: John Wiley \& Sons, Inc., 2008); McCoy et al., supra note 98 , at 1351 \& n.60; Wilmarth, supra note 108, at 1018-19, 1045.

120 Center for Public Integrity, "The Subprime 25," available at http://www.publicintegrity.org/investigations/economic_meltdown/the_subprime_25/full_list/(last visited on Sept. 28, 2009); John Dunbar \& David Donald, “The Roots of the Financial Crisis: Who Is to Blame?", Center for Public Integrity, May 6, 2009, available at http://www.publicintegrity.org/investigations/economic_meltdown/articles/entry/1286/ (last visited on Sept. 28, 2009); see also McCoy et al., supra note 98, at 1351-56 (describing leading roles of large federal thrifts and national banks in the subprime mortgage market); Wilmarth, supra note 108, at 1017-19 (describing growing presence of national banks and federal thrifts in the subprime mortgage market, and stating that "[a]fter 2000, large national banks and federal thrifts represented half or more of the top ten subprime lenders").

121 U.S. General Accountability Office, Financial Market Regulation: Agencies Engaged in Consolidated Supervision Can Strengthen Performance Measurement and Collaboration, GAO-07-154, Mar. 2007, at 12-14, 27-29, 40-41; Remarks by OTS Director John M. Reich at a Special Seminar on International Banking and Finance (Tokyo, Japan), Nov. 15, 2006, at 1-2, available at http://files.ots.treas.gov/87127.pdf.

${ }^{122}$ McCoy et al., supra note 98, at 1351-57; “Top Alt-A Lenders in 4Q 07," Mortgage Line, April 30, 2008, at 1 (listing HSBC, JP Morgan Chase (Chase), Flagstar, BB\&T, Lehman Brothers (Aurora), First Horizon, SunTrust, Wells Fargo, M\&T, Bear Stearns (EMC) and Fifth Third among the top 15 providers of Alt-A loans in the fourth quarter of 2007); “Top Alt-A Lenders in 3Q 07," National Mortgage News, Dec. 17, 2007, at 1 (listing Lehman Brothers (Aurora), Chase, Wamu, BofA, Bear Stearns (EMC), Flagstar, Wells Fargo, National City, First Horizon, Wachovia and BB\&T among the top 15 providers of Alt-A loans 
addition to their direct nonprime lending activities, national banks, federal thrifts and Wall Street firms provided indirect funding for subprime and Alt-A loans by furnishing wholesale lines of credit to nonbank lenders such as Ameriquest, New Century and Option One. When the major wholesale lenders cut off their lines of credit in 2007, many nonbank mortgage lenders and mortgage brokers quickly went out of business. The rapid disappearance of nonbank lenders and brokers confirmed that they were acting as conduits for the big national banks, federal thrifts and Wall Street firms. ${ }^{123}$

The largest federally-regulated financial institutions also created and marketed complex financial instruments whose performance was linked to nonprime mortgages, including residential mortgage-backed securities (RMBS), collateralized debt obligations (CDOs) and credit default swaps (CDS). Financial giants used CDOs and CDS to place multiple bets on nonprime mortgages and to facilitate the worldwide marketing of investment-grade securities derived from pools of nonprime mortgages. RMBS, CDOs and CDS magnified the impact of defaults on nonprime mortgages and triggered a global contagion of losses when the U.S. housing market collapsed. The OCC and the OTS, along with other federal regulators (including the Federal Reserve Board (FRB) and the SEC) failed to control the risks inherent in nonprime mortgages as well as the aggravation of those risks in RMBS, CDOs and CDS. ${ }^{124}$

The failures and federal bailouts of several large national banks, federal thrifts and W all Street firms revealed (i) the deep involvement of those institutions in the nonprime mortgage

in the third quarter of 2007); “Top Alt-A Lenders in First Half of 2007," National Mortgage News, Sept. 17, 2007, at 1 (listing IndyMac, Countrywide, Lehman Brothers (Aurora), Wamu, Bear Stearns (EMC), Chase, Wells Fargo, Wachovia and National City among the top 15 Alt-A lenders in the first half of 2007); “Top Alt-A Lenders in Q4 2005," National Mortgage News, April 10, 2006, at 1 (listing Bear Stearns (EMC), IndyMac, Lehman Brothers (Aurora), Wells Fargo, SunTrust, First Horizon, W achovia, BB\& T and Chase among the top 15 Alt-A lenders in the fourth quarter of 2005). Payment option ARMs gave borrowers several payment choices, including a negative amortization option that allowed borrowers to pay less than the accrued interest until the principal amount of their loans reached $110 \%$ or $120 \%$ of the original face amount, at which point the borrowers would be obligated to make much larger payments. Wilmarth, supra note 108 , at 1022 n.300.

${ }^{123}$ Dunbar \& Donald, supra note 120; see also Wilmarth, supra note 108, at 1018-20. For example, Citigroup, BofA and four Wall Street firms were the largest providers of warehouse loans to N ew Century, which ranked as the third largest subprime lender between 2005 and 2007. Id.

${ }^{124} \mathrm{McCoy}$ et al., supra note 98, at 1344-66; Wilmarth, supra note 108, at 968-71, 1011-35, 1046-48. 
debacle and (ii) serious regulatory failures by the OCC, the OTS and other federal regulators. On the OCC's side of the regulatory ledger, four of the sixteen largest national banks would have failed absent costly federal bailouts. The largest and third-largest national banks (BofA and Citigroup) suffered huge losses from nonprime-related activities and received mammoth bailout packages from the federal government, including $\$ 90$ billion of capital infusions and more than $\$ 400$ billion of asset price guarantees. ${ }^{125}$

In addition, the fourth-largest and sixteenth-largest national banks (Wachovia and National City) were pushed to the brink of failure by heavy losses resulting from risky nonprime lending. Federal regulators arranged a "hasty sale" of Wachovia to Wells Fargo and supported the transaction by infusing $\$ 25$ billion of capital into Wells Fargo. Federal regulators forced National City into a similar "shotgun marriage" with PNC, which was assisted by a federal infusion of $\$ 7.7$ billion of capital into PNC. ${ }^{126}$ It was ironic - but almost certainly not coincidental - that Wachovia and National City filed the lawsuits that ultimately led to the Supreme Court's decision in Watters, because both banks wanted to stop the states from regulating their mortgage operating subsidiaries. ${ }^{127}$ The foregoing disasters occurred despite the fact that the OCC maintained permanent teams of on-site examiners at each of the 17 largest national banks. ${ }^{128}$

On the OTS' side of the regulatory ledger, two of the largest thrifts (Wamu and IndyMac) failed after suffering devastating losses from reckless nonprime lending. Similar debacles

125 McCoy et al., supra note 98, at 1354; W ilmarth, supra note 108, at 1032-35, 1044.

${ }^{126}$ McCoy et al., supra note 98, at 1353-55; see also Wilmarth supra note 108, at 1044-45; Ari Levy, "Wells Fargo Chairman Prefers U.S. Plan to Buy Stakes (Update 2)," Bloomberg.com, Oct. 22, 2008; Dan Fitzpatrick et al., "PNC Buys National City in Bank Shakeout," Wall Street Journal, Oct. 25, 2008, at B1; “The PNC Financial Services Group, Inc.," Federal Reserve Bulletin, Mar. 2009, at B1, B7.

127 Wachovia and its mortgage lending subsidiary were the plaintiffs in Watters and also in a Second Circuit case that came before the Supreme Court while Watters was pending. Wachovia Bank, N.A. v. Burke, 414 F.3d 305 (2d Cir. 2005), cert. denied, 550 U.S. 913 (2007). National City and its mortgage lending subsidiary were the plaintiffs in a Fourth Circuit case that reached the Supreme Court while Watters was pending. National City Bank of Indiana v. Turnbaugh, 463 F.3d 325 (4th Cir. 2006), cert. denied, 550 U.S. 913 (2007).

128 Office of the Comptroller of the Currency, Annual Report, Fiscal Year 2008, at 13, available at http://www .occ.treas.gov/annrpt/1-2008 AnnualReport.pdf. 
occurred at AIG and three big Wall Street firms, all of which owned thrifts and were subject to oversight by the OTS. AIG was saved from bankruptcy by a huge federal bailout that grew to \$182.5 billion by March 2009. Lehman Brothers collapsed and filed for bankruptcy. To avoid a similar fate, Bear Stearns and Merrill Lynch entered into emergency, federally-assisted mergers with JP Morgan Chase and BofA. The OTS received heavy criticism for its shortcomings in regulating all six of the foregoing entities. The SEC was also at fault for failing to provide effective supervision of Bear Stearns, Lehman Brothers and Merrill Lynch. ${ }^{129}$ A recent study by Patricia McCoy, Andrey Pavlov and Susan Wachter analyzed delinquency rates on residential mortgage loans made by four categories of depository institutions between 2006 and 2008. The study found that loans made by federal thrifts had the highest delinquency rate and loans made by national banks had the second highest delinquency rate. In contrast, state banks had the lowest mortgage delinquency rate and state thrifts had the second lowest rate. ${ }^{130}$ In view of the substantially inferior lending performance of federally-chartered depository institutions, the study's authors rejected arguments by federal regulators that state authorities bore most of the blame for the subprime lending crisis. Instead, the authors concluded that the OCC, OTS and FRB were guilty of more serious regulatory lapses:

After the magnitude of the subprime debacle became known, federal regulators became adept at blaming the states for not regulating independent mortgage lenders and brokers effectively. Certainly, some states regulated these actors more heavily than others, and some states failed to regulate them at all. But the attack on the states obscures two essential facts. First, by the end of 2005, the majority of states had enacted comprehensive laws of varying streng ths to address improvident subprime loans. Indeed, proactive states adopted their laws years before the OCC, OTS, and the Federal Reserve Board took any meaningful action. Second, through their preemption rules, the OCC and OTS blocked enforcement of the most meaningful body of laws regulating reckless loan products - the state mini-HOEPA laws - for federal savings associations, national banks, and their mortgage lending subsidiaries. The Federal Reserve Board meanwhile refused to exercise its authority under HOEPA to correct the unlevel playing field by promulgating binding rules against unfair and deceptive

${ }^{129}$ McCoy et al., supra note 98, at 1352-53, 1358-66; William K. Sjostrom, Jr., "The AIG Bailout," 66 Washington and Lee Law Review (2009) (forthcoming) (working paper version at 2-3, 26-29, 41), available at http://ssrn.com/abstract=13465 52; Wilmarth, supra note 108, at 1045.

${ }^{130}$ McCoy et al., supra note 98 , at 1356 \& fig. 6. 
acts and practices that [would have] applied to virtually all lenders nationwide. As a result, meaningful regulation was non-existent at worst and ineffective at best for lenders cloaked with federal preemption and for lenders in unregulated states. ${ }^{131}$

As noted above, the briefs filed by NYAG Cuomo and supporting amici contained extensive allegations that the OCC's preemption rules and regulatory failings contributed to the severity of the subprime financial crisis. ${ }^{132}$ It seems likely that the Supreme Court's decision in Cuomo was influenced by those arguments. The comments made by Justices Ginsburg, Stevens and Souter during the Cuomo oral argument provide suggestive evidence of that influence.

\section{Unresolved Questions Concerning the Applicability of Chevron Deference to Preemption Claims by Federal Agencies}

Cuomo addressed, but did not resolve, two recurring questions concerning the appropriate judicial treatment of preemptive rulings by federal agencies. First, should courts give Chevron deference or a lower degree of deference to an agency regulation or order that includes a declaration of preemption? Second, should courts apply a presumption against preemption in evaluating agency claims of authority to override state laws in areas that the states have traditionally regulated?

Justice Stevens, who authored Chevron, addressed both of the foregoing questions in his dissenting opinion in Watters and again in his majority opinion in Wyeth. In those opinions, Justice Stevens indicated that Chevron deference should not be given to a federal agency's declaration of preemption unless Congress has made an explicit delegation of preemptive rulemaking authority to the agency. In place of Chevron, Justice Stevens' opinions provide the

131 Id. at 1357; see also id. at 1344-56 (presenting a detailed analysis of regulatory failings by the FRB, OTS and OCC); Binyamin Appelbaum, “As Subprime Lending Crisis Unfolded, Watchdog Fed Didn't Bother Barking," Washington Post, Sept. 27, 2009, at A1 (criticizing the FRB's failure to take effective action to control the risks of subprime lending by bank holding companies).

${ }^{132}$ See supra note 88 (citing amicus briefs filed in support of Mr. Cuomo). A preliminary version of the study by McCoy et al., supra note 98, was contained in congressional testimony presented by Professor McCoy on March 3, 2009. NYAG Cuomo's reply brief cited Professor McCoy's testimony. See Prepared Statement of Patricia A. McCoy before the U.S. Senate Committee on Banking, Housing, and Urban Affairs, Hearing on "Consumer Protections in Financial Services," March 3, 2009, available at http://ssrn.com/abstract=1367977 (cited in Reply Brief of Petitioner in Cuomo, at 28 n.12). 
basis for a more demanding, four-part test to determine the appropriate degree of deference that courts should apply in reviewing preemption claims by federal agencies. As part of that framework, the presumption against preemption would require a federal agency to present persuasive evidence showing that Congress intended to delegate authority permitting the agency to issue preemptive rules overriding state law in fields of traditional state regulation.

Justice Scalia took a significantly different approach to the question of judicial deference in his majority opinion in Cuomo. Justice Scalia said that he was applying Chevron in reviewing the validity of the OCC's "visitorial powers" rule. However, he applied a much less deferential version of Chevron than the approach advocated by Justice Thomas in his dissenting opinion. After making a careful evaluation of the OCC's claim of delegated authority, Justice Scalia concluded that the OCC's preemptive rule exceeded the limits of the OCC's power under the NBA. Thus, after Cuomo there is continuing uncertainty regarding the appropriate level of judicial deference for agency preemption claims.

\section{Justice Stevens' Treatment of Chevron in Watters and Wyeth}

In his dissenting opinion in Watters, Justice Stevens maintained that "the most pressing questions in this case are whether Congress delegated to the [OCC] the authority to preempt the laws of a sovereign State as they apply to operating subsidiaries [of national banks], and if so, whether that authority was properly exercised here." 133 Justice Stevens' framing of those questions in Watters was consistent with his opinion for the Court in Louisiana Public Service Comm'n v. FCC. ${ }^{134}$ In that case, the Court declared that "an agency literally has no power to act, let alone ... pre-empt the validly enacted legislation of a sovereign State, unless and until Congress confers power upon it." ${ }^{135}$

In Watters, Justice Stevens argued that Chevron did not provide the appropriate framework for reviewing the OCC's preemptive regulation. In his view, "when an agency

133 Watters, 550 U.S. at 38 (Stevens, J., dissenting).

134476 U.S. 355 (1986).

135 Id. at 374 . 
purports to decide the scope of federal preemption, a healthy respect for state sovereignty calls for something less than Chevron deference." ${ }^{136}$ He concluded that an agency's views on preemption should be entitled to "some weight" but only to the extent that the agency provided an "expert" opinion about the ways in which state law conflicted with the federal statutory scheme. ${ }^{137}$

In addition, Justice Stevens maintained that the Court should have applied a presumption against preemption in Watters, because the state mortgage lending laws in question were "designed to protect consumers" and "[c]onsumer protection is quintessentially 'a field which the States have traditionally occupied." "138 Based on that presumption, Justice Stevens contended that the OCC's preemptive regulation should have been struck down in the absence of any "clear and manifest purpose of Congress" to preempt the states' authority to regulate state-chartered operating subsidiaries of national banks. ${ }^{139}$

Justice Ginsburg's majority opinion in Watters carefully avoided the issue of Chevron deference and instead based its finding of preemption solely on the statutory provisions of the NBA. Justice Ginsburg declared that "the level of deference owed to the [OCC's] regulation is an academic question," because "the NBA itself - independent of the OCC's regulation -

${ }^{136}$ Watters, 550 U.S. at 41 (Stevens, J., dissenting). Justice Stevens' dissent in Watters was joined by Justice Scalia, who wrote the majority opinion in Cuomo, and also by Chief Justice Roberts, who joined the dissenting opinion in Cuomo. Thus, Justices Stevens and Scalia opposed the OCC's position in both cases, while Chief Justice Roberts switched from opposing the OCC in Watters to supporting the OCC in Cuomo. It appears that the decisive difference between the two cases for Chief Justice Roberts was that Watters considered the applicability of state laws to state-chartered operating subsidiaries of national banks, while Cuomo dealt with the authority of a state to enforce its laws directly against national banks. See Transcript of Oral Argument in Watters, supra note 110, at 28 (question by Chief Justice Roberts, asking why "a separate subsidiary that is not a national bank ... is immune from [state] regulation"); id. at 51-52 (inquiry by Chief Justice Roberts, questioning why a national bank can "take advantage of [state limited liability protection] by establishing a subsidiary chartered under State law . . . and yet they're claiming immunity from all other State regulations?"). Chief Justice Roberts exhibited a very different attitude toward state authority during the oral argument in Cuomo. In response to New York's claim of authority to enforce its fair lending law against national banks, the Chief Justice cited McCulloch v. Maryland, 17 U.S. (4 Wheat.) 316 (1819), and he suggested that Congress had "an historical reason" to be concerned that "[n]ational banks were always targeted by the States" and therefore needed special protection from state enforcement. Transcript of Oral Argument in Cuomo, supra note 50, at 16. The Chief Justice also indicated that he viewed "Federal policy" as favoring a uniform regulatory regime governing national banks throughout the nation. Id. at 9.

137 Watters, 550 U.S. at 41 (Stevens, J., dissenting) (quoting Geier v. American Honda Motor Co., 529 U.S. 861,883 (2000)).

${ }_{138}$ Id. (quoting Rice v. Santa Fe Elevator Corp., 331 U.S. 218, 230 (1947).

139 Id. at 35-36 (quoting Rice, 331 U.S. at 230). 
preempts the application of the pertinent Michigan laws to national bank operating

subsidiaries." 140 She maintained that any argument concerning the propriety of Chevron

deference "is beside the point" because the OCC's regulation "merely clarifies and confirms what

the NBA already conveys." 141

In his majority opinion in Wyeth, Justice Stevens returned to the question of whether a federal agency's claim of preemption should receive Chevron deference. Once again, he indicated that Chevron does not provide the appropriate framework for reviewing agency assertions of preemption, except in situations where Congress has explicitly granted preemptive rulemaking authority to an agency. In that context, Justice Stevens declared that "agencies have no special authority to pronounce on preemption absent delegation by Congress." ${ }^{142}$

Justice Stevens explained in Wyeth that the Supreme Court had previously reviewed agency claims of preemption by "perform[ing] its own conflict determination, relying on the substance of state and federal law and not on agency proclamations of pre-emption." ${ }^{143}$ In such cases, Justice Stevens emphasized that “we have not deferred to the agency's conclusion that state law is pre-empted." Instead, "we have given 'some weight' to an agency's views . . . about how state requirements may pose an 'obstacle to the accomplishment of the full purposes and objectives of Congress." "144 In Justice Stevens' view, “[t]he weight we accord to the agency's

\footnotetext{
${ }^{140}$ Id. at $20,21 \mathrm{n} .13$.

${ }^{141} I d$. at $20-21$.

142 Wyeth, 129 S. Ct. at 1201 ; see also id. at 1201 \& n.9 (stating that "Congress has not authorized the FDA to preempt state law directly," and giving examples of other federal statutes that expressly authorized agencies to a dopt regulations preempting state law); Watters, 550 U.S. at 38 \& n.21 (Stevens, J., dissenting) (stating that "Congress knows how to authorize executive agencies to preempt state laws" and giving similar examples of federal statutes that expressly delegated preemptive rulemaking authority to agencies). Unlike his dissenting opinion in Watters, Justice Stevens' majority opinion in Wyeth did not explicitly reject the applicability of Chevron. However, as discussed infra at notes 145-47 and accompanying text, Justice Stevens' opinion in Wyeth strongly indicated that Skidmore rather than Chevron provided the appropriate level of judicial deference for agency claims of preemption.

143 Wyeth, 129 S. Ct. at 1201.

144 Id. (quoting Geier, 529 U.S at 883, and Hines v. Davidowitz, 312 U.S. 52, 67 (1941)).
} 
explanation of state law's impact on the federal scheme depends on its thoroughness, consistency, and persuasiveness." 145

Justice Stevens' majority opinion in Wyeth did not define the precise degree of "weight" that courts should give to agency claims of preemption. However, his citation to Skidmore and his reference to the Skidmore factors of "thoroughness, consistency, and persuasiveness" indicated that agency preemptive determinations should receive the relatively low level of deference described in Skidmore. ${ }^{146}$ In addition, Justice Stevens maintained in Wyeth that a presumption against preemption should apply "[i]n all preemption cases, and particularly those in which Congress has 'legislated in a field which the States have traditionally occupied." 147 As he had previously indicated in his dissent in Watters, Justice Stevens did not believe that the presumption against preemption should be set aside simply because a federal agency had issued a finding of preemption.

In Wyeth, the Food and Drug Administration ("FDA") declared in a preamble to a final regulation that tort claims under state law were preempted by federal statutes regulating the labeling of prescription drugs. For two reasons, the Supreme Court refused to give any deference to the FDA's preemption claim. First, when the FDA issued the proposed regulation for public comment, the FDA said that the regulation would not preempt state law. The FDA did not notify the public of any change in its position until the agency published its final rule. At that point, the FDA suddenly inserted a declaration of preemption into the preamble without any advance notice or any opportunity for public comment on the preemption issue. The Court concluded that the FDA's preemption claim was "inherently suspect in light of this procedural failure." 148

145 Id. (citing United States v. Mead Corp., 533 U.S. 218, 234-35 (2001), and Skidmore v. Swift \& Co., 323 U.S. 134, 140 (1944)).

146 Id.; see also Skidmore, 323 U.S. at 140 (stating that " $[\mathrm{t}]$ he weight of [the agency's] judgment in a particular case will depend upon the thoroughness evident in its consideration, the validity of its reasoning, its consistency with earlier and later pronouncements, and all those factors which give it power to persuade, if lacking power to control").

147 Wyeth, 129 S. Ct. at 1194 (quoting Metronic v. Lohr. 518 U.S. 470, 485 (1996) (quoting Rice, 331 U.S. at 230)).

${ }^{148}$ Id. at 1201 . 
Second, the Court determined that the FDA's assertion of preemption "is at odds with what evidence we have of Congress' purposes, and it reverses the FDA's own longstanding position [of non-preemption] without providing a reasoned explanation, including any discussion of how state [tort] law has interfered with the FDA's regulation of drug labeling during decades of coexistence." ${ }^{149}$ In view of the fact that "Congress has repeatedly declined to pre-empt state [tort] law" with respect to prescription drugs, the Court held that the FDA's claim of preemption was "entitled to no weight." 150

\section{Justice Stevens' Four-Part Framework for Determining the Appropriate Level of Judicial Deference for Agency Preemption Claims}

Justice Stevens did not articulate a precise formula for reviewing agency assertions of preemptive authority in his dissenting opinion in Watters or his majority opinion in Wyeth. However, a four-part framework for determining the appropriate level of judicial deference for agency preemption claims can be derived from those opinions. As explained below, that fourpart test would strike an appropriate balance between (i) the granting of some deference to the specialized expertise of administrative agencies and (ii) the judiciary's responsibility to ensure that preemption issues are resolved in accordance with constitutional and statutory limits on federal power.

\section{First, Chevron deference is inapplicable absent an explicit delegation of preemptive} rulemaking authority to the agency. In his opinions in Watters and Wyeth, Justice Stevens indicated that a federal agency's preemptive regulation should not receive Chevron deference unless Congress has expressly granted preemptive rulemaking power to the agency. ${ }^{151}$ This

149 Id. The three dissenters in Wyeth did not contend that the FDA's preemption claim should receive Chevron deference. Instead, they argued that the FDA's position was entitled to "some weight" under Geier and should have been upheld. They also contended that it was irrelevant that the FDA's preemption claim was not adopted through notice-and-comment rulemaking or that it represented a change in the agency's position. Id. at 1227-29 (Alito, J., dissenting).

150 Id. at 1201-04 (quotes at 1204).

151 Watters, 550 U.S. at 38-39, 41 (Stevens, J., dissenting); see also Wyeth, 129 S. Ct. at 1201 \& n.9. Justice Stevens emphasized in Watters that Congress had not made an explicit grant of preemptive rulemaking authority to the OCC. He described the OCC's rulemaking powers under 12 U.S.C. $\S \S 93$ a and 371 (a) as "generic authorizations of rulemaking authority . . and neither says a word about preemption. ... Needless to say, they provide no textual foundation for the OCC's assertion of preemption authority." 
requirement would ensure that a federal agency cannot appeal to Chevron unless its preemption claim is based on an explicit statutory grant of preemptive authority rather than merely the agency's "interpretation" of an ambiguous statute. As Justice Stevens explained in Watters, granting Chevron deference to preemptive agency rulings based on ambiguous statutes would grant federal agencies a far-reaching power to override state law, except in those rare situations where Congress has unambiguously barred an agency from acting. ${ }^{152}$

The opinions of the Second Circuit and Justice Thomas in Cuomo reveal the inadequacy of highly deferential review in the context of agency preemption. The Second Circuit stated that "[a]lthough the precise scope of 'visitorial' powers is not entirely clear from the text of [12 U.S.C.] $\S 484(a), \ldots$ we cannot agree . . . that the statute clearly precludes the interpretation the OCC has adopted." 153 Similarly, Justice Thomas argued in his dissenting opinion in Cuomo that, under Chevron, the Court was required to "decide only whether the construction adopted by the $[\mathrm{OCC}]$ is unambiguously foreclosed by the statute's text." 154 As a practical matter, the approach followed by the Second Circuit and Justice Thomas in Cuomo would have created a virtually conclusive presumption in favor of the OCC's authority to preempt the states' sovereign law enforcement powers, even though the OCC was relying on an admittedly ambiguous statute. ${ }^{155}$

Watters, 550 U.S. at $39 \&$ nn.22-23 (Stevens, J., dissenting).

${ }^{152}$ Id. at 41 ("No case from this Court has ever applied such a deferential standard to an agency decision that could so easily disrupt the federal-state balance. . . [W]ith relative ease [federal agencies] can promulgate comprehensive and detailed regulations that have broad preemption ramifications for state law. ... For that reason, when an agency purports to decide the scope of federal preemption, a healthy respect for state sovereignty calls for something less than Chevron deference.") (internal quotation marks and citations omitted); see also id. at $39 \&$ n. 23 (maintaining that Congress had not delegated any preemptive rulemaking authority to the OCC).

153 Cuomo, 510 F.3d at 117.

154 Cuomo, 129 S. Ct. at 2733 (Thomas, J., dissenting in part).

155 As previously noted, both the majority and dissenting opinions in Cuomo determined that the term "visitorial powers" in 12 U.S.C. $\$ 484$ contained at least "some ambiguity" with respect to the question of whether $\S 484$ barred judicial enforcement actions by state officials against national banks. See supra note 17 and accompanying text. Prior to Cuomo, the Supreme Court affirmed the sovereign nature of the states' law enforcement powers in several cases, including Calderon v. Thompson, 523 U.S. 538, 556 (1998); Diamond v. Charles, 476 U.S. 54, 65 (1986); Heath v. Alabama, 474 U.S. 82, 89, 93 (1985); and Bartkus v. Illinois, 359 U.S. 121, 137 (1959). In his dissent from the Second Circuit's decision in Cuomo, Judge Cardamone argued that "[i]t is difficult to imagine a more core aspect of state sovereignty than the authority to pass and enforce valid nonpreempted state laws." Cuomo, 510 F.3d at 131 (Cardamone, J., dissenting). 
In Gregory v. Ashcroft, ${ }^{156}$ the Supreme Court declared that the power of Congress to adopt legislation preempting "areas traditionally regulated by the States ... is an extraordinary power in a federalist system. It is a power that we must assume Congress does not exercise lightly." 157 The Court therefore held that Congress must "make its intention 'clear and manifest' if intends to pre-empt the historic powers of the States."158

Because Gregory involved a claim of statutory rather than regulatory preemption, Gregory did not consider the issue of whether courts should apply Chevron in reviewing agency preemptive rulings. However, Gregory's reasoning strongly supports the view that Chevron should not apply when a federal agency's claim of preemptive authority rests on an ambiguous statute. Gregory held that the courts may not conclude that a statute alters "the state-federal balance" in the absence of a "plain statement" of Congress' intent to change that balance. The Court explained that this "plain statement rule" helps to ensure that "the political process" has given appropriate consideration to the states' interest in being protected "against intrusive exercises of Congress' Commerce Clause powers." 159 In addition, as the Court observed, to "give the state-displacing weight of federal law to mere congressional ambiguity would evade the very procedure for lawmaking on which Garcia relied to protect states' interests."160

\footnotetext{
156501 U.S. 452 (1991).

157 Id.at 460.

158 Id. (quoting Rice v. Santa Fe Elevator Corp., 331 U.S. 218,230 (1947)).

159 Id. at 460-61, 464-67 (quotes at 461, 464).

${ }^{160}$ Id. at 464 (quoting Laurence H. Tribe, American Constitutional Law $\S 6-25$ at 480 (Mineola, NY: Foundation Press, 2d ed. 1988), and citing Garcia v. San Antonio Metropolitan Transit Auth., 469 U.S. 528 (1985)). Thus, Gregory reflects the Supreme Court's view that "a clear statement requirement is necessary in order to ensure compliance with federal lawmaking procedures and to protect the residual authority of the states under the Supremacy Clause." Bradford R. Clark, "Process-Based Preemption," in William W. Buzbee, ed., Preemption Choice: The Theory, Law, and Reality of Federalism's Core Question (Cambridge, UK: Cambridge University Press 2009), at 191, 204. Professor Clark has explained that the Supremacy Clause (the constitutional source of the preemption doctrine) and other provisions of the Constitution are "carefully structured to restrict both who may exercise lawmaking power on behalf of the United States (actors subject to the political safeguards of federalism) and how they may exercise it (only in accordance with precise procedures that require the participation and assent of the states or their representatives in the Senate)." Id. at 195-97 (quote at 197). Accordingly, "[i]f judges permit an ambiguous provision of a federal statute to preempt state law, they risk circumventing federal lawmaking procedures and the political safeguards [of federalism] they incorporate." Id. at 204-05.
} 
Granting Chevron deference to preemptive agency rulings based on ambiguous statutes would clearly undermine the federalism-based canons articulated in Gregory. Gregory bars courts from relying on ambiguous statutes to infer a congressional intent to preempt traditional state functions. Similarly, courts should not allow a federal agency to infer a preemptive congressional purpose based solely on the agency's "interpretation" of a statute that is silent or ambiguous with regard to any such purpose.

To preserve our federal structure, Gregory's ban on judicial inference of preemptive intent from ambiguous statutes should apply with at least equal force when federal agencies claim to speak for Congress in asserting preemption based on statutory ambiguity. Unlike Congress, federal agencies are less vulnerable to discipline from "the political process" and do not provide the states with any constitutionally-guaranteed structure of representation that would promote a vigorous and thorough discussion of the states' interests and concerns before a preemptive regulation is adopted. Justice Stevens declared in Watters that federal agencies should not receive Chevron deference when they issue preemptive rulings because such agencies "are clearly not designed to represent the interests of States." ${ }^{161}$ For similar reasons, Nina Mendelson contends that courts should not defer to an agency's assertion of preemptive authority over an area in which Congress has not clearly expressed its intent to displace state law:

$[R]$ equiring a showing that Congress clearly wishes to preempt state law ... gives some protection to state regulatory autonomy. ... [A] presumption [against preemption] also helps assure that legislative decisions to preempt are thoughtful and deliberate rather than simply 'incidental.' ... $\ldots$

Although state institutions have the opportunity to comment on rulemaking through the notice-and comment process, those comments are likely to be lower-visibility, both to

161 Watters, 550 U.S. at 41 (Stevens, J., dissenting) (quoting Geier, 529 U.S. at 883 (Stevens, J., dissenting)); see also Cass R. Sunstein, "Nondelegation Canons," 67 University of Chicago Law Review 315, 331 (2000) (explaining that "the idea that administrative agencies will not be allowed to interpret ambiguous [statutory] provisions so as to preempt state law ... [is] an important requirement in light of the various safeguards against cavalier disregard of state interests created by the system of state representation in Congress"); Clark, supra note 160, at 213 (agreeing with Professor Sunstein's suggestion that "the preemption decision must be made legislatively, not bureaucratically" in view of the "constitutional commitment to a federal structure") (quoting Sunstein, supra, at 331). 
decisionmakers and to the public, than objections raised by a member of Congress to a legislative proposal. ...

[A]gencies, unlike Congress and the courts, are specialized institutions that are not set up to consider state autonomy concerns. ${ }^{162}$

Professor Mendelson and Thomas Merrill contend that federal agencies are subject to additional institutional limitations (including a tendency toward "empire building" and a bias against allowing regulatory "competition" from the states) that undermine the agencies' ability to resolve preemption issues in a manner that gives appropriate weight to the interests of state autonomy within our federal system. ${ }^{163}$ After considering similar factors based on institutional competence and motivation, Professor Merrill concludes that courts are better suited to resolve preemption issues that arise out of ambiguous federal statutes. Accordingly, he contends that courts should not give Chevron deference to agency preemption claims based on statutory ambiguity:

[A]lthough preemption entails the resolution of policy disputes, those disputes have significant dimensions along which courts are likely to perform better than agencies dimensions such as preserving fidelity to the Constitution's division of powers, the need for preserving stability in that division, the desirability of preserving an overall balance between federal and state authority, and the need to discern accurately the nature and content of state law alleged to be in tension with federal law. ${ }^{164}$

\footnotetext{
${ }^{162}$ Nina A. Mendelson, “A Presumption Against Agency Preemption,” 102 Northwestern Law Review 695, 710,717 (2008).

${ }^{163}$ Id. at 717-22; Thomas W. Merrill, "Preemption and Institutional Choice," 102 Northwestern Law Review 727, 755-57, 772-73 (2008) (quotes at 756). In contrast, Brian Galle and Mark Seidenfeld contend, based on a "realist approach to administrative law" and a "functional analysis of . . the relative institutional competence of the three branches" of federal government, that "agencies are in many contexts better suited to consider federalism concerns than are Congress or the federal judiciary." Brian Galle \& Mark Seidenfeld, “Administrative Law's Federalism: Preemption, Delegation, and Agencies at the Edge of Federal Power," 57 Duke Law Review 1933, 1938-39, 1948-49 (2008). Professors Galle and Seidenfeld explain that their "functional" analysis is directed at "improving the regulatory process, not the preservation of state regulatory prerogatives per se." Id. at 1949. Thus, their "realist approach" does not seek to justify or defend any "formalistic preference for protection of dual sovereignty." Id. at 1938, 1949.

${ }^{164}$ Merrill, supra note 163, at 772; see also id. at 757-59 (concluding that, "[t]aking all these factors into consideration,... courts should continue to function as the institution that has the last word on whether to displace state law through preemption," id. at 759). In contrast, Professors Galle and Seidenfeld maintain that "any doctrinal trend to ward requiring in all cases clear congressional authorization for [agency] preemption . . . is mistaken." Galle \& Seidenfeld, supra note 163, at 1940. They conclude, based on institutional considerations of "accountability, transparency, and deliberativeness," that "federal agencies should often be the preferred institutions in which to vest the authority to allocate power between the states and federal government." Id. at 1948, 1936.
} 
Second, no deference should be given to agency interpretations of statutes, judicial precedents and other legal authorities that do not require specialized agency expertise. Justice Stevens' opinion in Wyeth supports the view that courts should not defer to an agency's legal conclusions about preemption based on the agency's interpretations of statutes, Supreme Court precedents or other legal authorities that do not require the agency to apply its specialized expertise. ${ }^{165}$ Moreover, in a 2004 decision authored by Justice Stevens, the Supreme Court held that "'pure question[s] of statutory construction ... well within the province of the Judiciary ... merit no special deference," and the Court further explained that an agency's "views on questions within its area of expertise merit greater deference than its opinions regarding the scope of a congressional enactment." 166 Similarly, the Court recently declared that "[a]gencies have no special claim to deference in their interpretation of our decisions." ${ }^{167}$

Third, "some weight" may be given to an agency's expert analysis of the ways in which $\underline{\text { state laws conflict with the statutory scheme administered by the agency, but courts should }}$

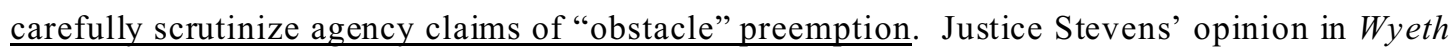
indicates that courts should give "some weight" to an agency's analysis of alleged conflicts between state laws and the governing federal statute, provided the agency's analysis is based on matters within the agency's special expertise and otherwise has "power to persuade" under Skidmore. Thus, courts should consider evidence showing that the agency has made "informed

\footnotetext{
165 Wyeth, 129 S. Ct. at 1200-01.

166 Republic of Austria v. Altmann, 541 U.S. 677, 701, 702 n.23 (2004) (opinion for the Court by Stevens, J.) (quoting INS v. Cardoza-Fonseca, 480 U.S. 421, 466, 468 (1987) (same). Similarly, in Cuomo the Second Circuit found it "troublesome" that the "administrative record [supporting the OCC's claim of exclusive enforcement powers over national banks] consists almost entirely of the agency's interpretations of case law, legislative history, and statutory text. ... These are not subjects on which the OCC holds any special expertise." Cuomo, 510 F.3d at 118 . The Second Circuit also observed that "the OCC does not appear to have found any facts at all in promulgating its visitorial powers regulation. It accretes a great deal of regulatory authority to itself at the expense of the states through rulemaking lacking any real intellectual rigor or depth." Id..

167 Ledbetter v. Goodyear Tire \& Rubber Co., 550 U.S. 618, 642 n.11 (2007), superseded by statute on other grounds, Pub. L. No. 111-2, 123 Stat. 5 (codified at 42 U.S.C. $§ 2000 \mathrm{e}-5(\mathrm{e})$ ).
} 
determinations about how state requirements may pose an 'obstacle to the accomplishment and execution of the full purposes and objectives of Congress." "168

Even here, Professor Mendelson warns that courts should closely scrutinize an agency’s claim that state law presents an "obstacle" to the accomplishment of congressional purposes. In her view, courts should carefully evaluate the content and strength of legislative policies inherent in federal statutes and should determine whether state laws actually create significant conflicts with those policies. Otherwise, "federal agencies would have the power to preempt nearly any state law ... as long as the agency can explain how the state law strikes a different balance of statutory objectives than the federal [agency's] approach does."169

Similarly, William Buzbee contends that federal agency claims of "obstacle" preemption should be subject to "hard look review," including (i) "close scrutiny of agency factual and policy conclusions," and (ii) a careful evaluation of the agency's decisionmaking process to ensure that the "agency engaged the views of affected stakeholders, considered underlying facts or data in dispute, and addressed them in a reasonable way." ${ }^{\prime 10}$ Professor Buzbee notes that agency claims of conflict preemption frequently turn on the agency's "assertions about benefits and harms of allowing multiple [state and federal] regulatory voices or displacing all but a single, federal regulatory actor."171 Unless courts engage in "hard look" review that insists upon an "open and deliberative agency process," he fears that federal agencies will often discount or ignore the benefits of preserving a federalist system with multiple regulators. In this regard, he believes that overlapping federal-state regulatory systems "improve the odds of superior regulatory outcomes" by (i) reducing the risk of policy mistakes by a single, all-powerful regulator whose decisions are difficult to challenge or correct, (ii) increasing "opportunities for mutual adjustment and learning"

168 Wyeth, 129 S. Ct. at 1202 (quoting Hines, 312 U.S. at 67).

169 Mendelson, supra note 162 , at 714.

170 William W. Buzbee, "Preemption Hard Look Review, Regulatory Interaction, and the Quest for Stewardship and Intergenerational Equity," 77 George Washington Law Review 1521, 1557-69 (2009) (quote at 1569).

${ }^{171} I d$. at 1556. 
by multiple regulators with concurrent jurisdictions, and (iii) preserving the "states as laboratories of [experimentation and] democracy.",172

Fourth, a presumption against preemption applies whenever an agency seeks to preempt a traditional state function. Justice Stevens' opinion in Wyeth indicates that courts should not defer to an agency's preemption claim under Skidmore unless the agency's case for preemption is sufficiently strong to overcome the presumption that Congress does not intend to preempt state law in areas of traditional state regulation. In Wyeth, Justice Stevens rejected the FD A's claim that state tort suits presented an "obstacle" to congressional objectives regarding the labeling of prescription drugs. Justice Stevens noted that Congress adopted an express preemption statute covering medical devices in 1976 but failed to do so with respect to prescription drugs. In view of the presumption against preemption of state laws in the field of consumer protection, Justice Stevens determined that the "silence [of Congress] on the issue, coupled with its certain awareness of the prevalence of state tort litigation, is powerful evidence that Congress did not intend FDA oversight to be the exclusive means of ensuring drug safety and effectiveness" ${ }^{\text {173 }}$

Four justices joined Justice Stevens' majority opinion in Wyeth. ${ }^{174}$ However, it is debatable whether a majority of the Court fully supported Justice Stevens' suggested framework for judicial deference. In addition to joining the majority opinion in Wyeth, Justice Breyer filed a concurring opinion indicating that he might have given the FDA's preemption claim greater deference if it had been adopted through notice-and-comment rulemaking. ${ }^{175}$ Justice Thomas did

${ }^{172} I d$. at $1576-78$.

173 Wyeth, 129 S. Ct. at 1194-95, 1200 (quote). Professor Buzbee agrees that courts should apply a presumption against preemption when they review agency claims of preemptive authority. As he points out, "[i]f preemption is ultimately a question of congressional intent, shaped against a constitutional norm of retained state concurrent power, then agencies [like Congress] should have to overcome the presumption against preemption." Id. at 1564 .

174 The group of Justices joining the majority opinion in Wyeth was the same as in Cuomo, except that Justice Kennedy joined the majority opinion in Wyeth but not in Cuomo, while Justice Scalia took the opposite position in both cases.

${ }^{175}$ Wyeth, 129 S. Ct. at 1204 (Breyer, J., concurring). 
not join the majority opinion in Wyeth and instead filed an opinion concurring only in the judgment. ${ }^{176}$

\section{The Application of Chevron in Cuomo and the Relevance of Gonzales and Brand $X$}

As previously noted, Justice Scalia cited Wyeth with approval in his majority opinion in Cuomo. ${ }^{177}$ However, Justice Scalia did not adopt the analytical approach for reviewing agency preemption claims that Justice Stevens suggested in Wyeth. Justice Scalia instead explained that he was applying "the familiar Chevron framew ork." 178 Even so, Justice Scalia's application of Chevron gave little deference to the OCC and instead carefully scrutinized the OCC's claim of preemptive authority.

Cuomo and Gonzales v. Oregon: With regard to the first step of Chevron-determining whether "the intent of Congress is clear" $" 179$ - Justice Scalia declared that the existence of "some ambiguity" in 12 U.S.C. $\S 484(a)$ "does not expand Chevron deference to cover virtually any interpretation of the [NBA]." 180 Justice Scalia's refusal in Cuomo to grant Chevron deference, based simply on statutory ambiguity, was similar to the Supreme Court's approach in Gonzales v. Oregon. ${ }^{181}$ In Gonzales, the Court held that "Chevron deference . . is not accorded merely because the statute is ambiguous and an administrative official is involved. [Rather,] the rule must be promulgated pursuant to authority Congress has delegated to the official."182

Additionally, the Court warned in Gonzales that if an agency claims "broad and unusual authority

${ }^{176}$ Id. (Thomas, J., concurring in the judgment). Justice Thomas contended that the FDA's preemption claim should be struck down because it relied on a theory of implied preemption (which he rejected as unconstitutional) instead of express statutory preemption. Id. at 1205, 1207 (arguing that the Supremacy Clause "requires that pre-emptive effect be given only to those federal standards and policies that are set forth in, or necessarily follow from, the statutory text that was produced through the constitutionally required bicameral and presentment procedures"). Justice Thomas evidently did not have the same problem with the OCC's preemptive rule in Cuomo because the OCC relied on a statute - 12 U.S.C. $\S 484($ a) - that expressly preempted state law, even though the statute did not explicitly grant preemptive rulemaking authority to the OCC. See Cuomo, 129 S. Ct. at 2722-23, 2732-33 (Thomas, J., dissenting in part).

177 Cuomo, 129 S. Ct. at 2718.

$178 I d$. at 2715.

179 Chevron, 467 U.S. at 842.

180 Cuomo, 129 S. Ct. at 2715.

181546 U.S. 243 (2006).

182 Id. at 258; see also Adams Fruit Co. v. Barrett, 494 U.S. 638, 649 (1990) ("A precondition to deference under Chevron is a congressional delegation of administrative authority"). 
through an implicit delegation" based on "vague terms" in the governing statute, the Court may well conclude that "Congress could not have intended to delegate a decision of such economic and political significance to an agency in so cryptic a fashion." 183

In Gonzales, the US Attorney General issued an interpretive rule barring doctors from prescribing drugs to be used in assisted suicides. The Attorney General's rule specifically preempted any state law authorizing state-licensed physicians to prescribe drugs for that purpose. The Supreme Court struck down the rule because (i) the Attorney General's claim of preemptive authority would "effect a radical shift of authority from the States to the Federal Government to define general standards of medical practice in every locality," and (ii) the "text and structure of the [governing federal statute] show that Congress did not have this far-reaching intent to alter the federal-state balance." ${ }^{184}$ Justice Scalia's refusal in Cuomo to give the OCC wide leeway in inferring preemptive authority from statutory ambiguity was consistent with the limitations on Chevron deference expressed in Gonzales.

With regard to the second step of Chevron - determining whether the OCC made a "reasonable interpretation" of the $\mathrm{NBA}^{185}$ - Justice Scalia concluded in Cuomo that historical evidence and judicial precedents enabled the Court (i) to "discern the outer limits" of $\S 484(a)$ and (ii) to determine that the OCC exceeded its authority in defining "visitorial powers" to include "ordinary enforcement of the law."186 As previously discussed, Justice Scalia held that applicable federal statutes did not contemplate the "bizarre" result produced by the OCC's

183 Gonzales, 546 U.S. at 267 (internal quotation marks and citations omitted).

${ }^{184} I d$. at 253-54, 275. On similar grounds, a federal appellate court invalidated a ruling issued by the Federal Trade Commission (FTC) that sought to impose federal privacy requirements on attorneys by classifying them as "financial institutions." American Bar Ass'n v. FTC, 430 F.3d 457 (D.C. Cir. 2005). The court held that "Congress has not made an intention to regulate the practice of law 'unmistakably clear' in the language of the [governing federal statute]." Id. at 472. Accordingly, the court rejected the FTC's attempt to rely on an ambiguous statute to regulate "the practice of law [which] is traditionally the province of the states." Id. at 471 .

185 Chevron, 467 U.S. at 843-44.

186 Cuomo, 129 S. Ct. at 2715. 
regulation - namely, a preemptive bar that would override "traditional state powers" to enforce valid state laws against national banks through judicial proceedings. ${ }^{187}$

Justice Scalia's careful analysis of whether Congress affirmatively delegated the preemptive authority claimed by the OCC could be viewed as supporting either of two possible approaches to the application of Chevron in similar agency preemption cases. Each of those approaches would strengthen judicial scrutiny of preemptive agency rulings under Chevron. The first possibility is that the question of whether the agency has received an adequate delegation of statutory preemptive authority should be made at "step zero," before a reviewing court even begins to apply the two-step Chevron analysis. ${ }^{188}$

The second possibility is that a reviewing court should examine the question of congressionally delegated authority at "step 2.1" of the Chevron analysis. Under this approach, if a reviewing court finds at "step one" that the agency has based its preemptive ruling on an ambiguous statute, the court should then decide at the beginning of "step two" whether Congress has affirmatively delegated preemptive authority to the agency, before the court proceeds to determine whether the agency has made a "reasonable" interpretation of the ambiguous statute. Thus, under a "step 2.1" approach,

the court must carefully consider whether Congress has authorized the agency to adopt a preemptive regulation to clarify the ambiguity or to fill the "gap" that the agency has identified in the governing statute.

Only if the court answers "yes" at "step 2.1" may the court then proceed to a more deferential analysis of whether the agency has made a "reasonable" interpretation of the statute. ... [I]f the agency adopts an "interpretation" of a statute that . . encroaches upon an area traditionally regulated by the states, the reviewing court should require a

187 Id. at 2718,2720 .

188 See Thomas W. Merrill \& Kristin E. Hickman, “Chevron's Domain,” 89 Georgetown Law Review 833, 910-13 (2001) (contending that (i) the courts should decide at "step zero" the comparable question of whether Chevron deference should be granted to an agency's interpretation of the scope of its delegated authority, and (ii) the courts should decide that question by asking "whether Congress would want the particular question about the scope of agency authority to be resolved" by the agency acting as "the primary interpreter of the agency's jurisdiction"); but see Cass R. Sunstein, "Chevron Step Zero," 92 Virginia Law Review 187, 248 ((2006) (arguing that "[c]onstraints on administrative discretion, rooted in the rule of law, ... should be supplied not through Step Zero but through other means, above all through an emphasis on the limitations recognized in Chevron itself"). 
clear showing that the agency's "interpretation" is consistent with the available evidence of Congress' intent. ${ }^{189}$

Gonzales and Cuomo followed an analytical approach that could be viewed as fitting within the "step 2.1" formulation. In each case, the Court first determined that there was some degree of ambiguity in the governing federal statute. ${ }^{190}$ In each case, the Court proceeded to make a careful analysis of whether the federal agency's preemptive ruling was supported by a sufficient congressional delegation of preemptive authority. Finding that the available evidence of congressional intent did not support such a delegation, the Court concluded in each case that the agency's preemptive ruling was invalid and not entitled to deference. ${ }^{191}$

In Gonzales, the Court shifted from a Chevron analysis to the less deferential standard of Skidmore after the Court concluded that the challenged ruling "was not promulgated pursuant to the Attorney General's [statutory] authority." "192 In Cuomo, the Court did not make an explicit shift from Chevron to Skidmore. However, Justice Scalia closely scrutinized the OCC's claims of authority in a manner that suggested a less deferential, Skidmore type of inquiry.

In my view, the four-part framework for judicial deference derived from Justice Stevens' opinions in Watters and Wyeth would provide a superior methodology for analyzing agency preemption claims based on ambiguous statutes. By completely avoiding the Chevron mode of analysis, the four-part framework would encourage reviewing courts to perform an independent and thorough consideration of the federalism-related factors discussed in Gregory. If, however, the Supreme Court ultimately decides to choose Chevron as the governing standard for evaluating preemptive agency rulings, the Court should make clear - as it indicated in Gonzales and Cuomo - that preemptive rulings are subject to heightened judicial scrutiny on the issue of whether Congress has affirmatively delegated the preemptive authority asserted by the agency. Such

189 Arthur E. Wilmarth, Jr., "OCC v. Spitzer: An Erroneous Application of Chevron That Should Be Reversed," 86 Banking Report (BNA) 379, 386 (2006), available at http://ssrn.com/abstract=886380.

190 Gonzales, 546 U.S. at 258; Cuomo, 129 S. Ct. at 2715.

191 Gonzales, 546 U.S. at 258-75; Cuomo, 129 S. Ct. at 2716-22.

192 Gonzales, 546 U.S. at 269. 
enhanced scrutiny could be applied in accordance with either of the "step zero" or "step 2.1" approaches discussed above.

In contrast to Justice Scalia's searching analysis of the OCC's delegated authority in Cuomo, Justice Thomas' dissenting opinion illustrates the pitfalls of applying a highly deferential version of Chevron in a case where the agency's preemptive ruling is based on an ambiguous statute. Justice Thomas maintained that the OCC was entitled to Chevron deference because the agency had "selected a permissible construction of a statutory term that was susceptible to multiple interpretations." 193 In addition, as previously noted, he argued that under Chevron "[t]he Court must decide only whether the construction adopted by the agency is unambiguously foreclosed by the statute's text." 194

As a practical matter, Justice Thomas' implementation of Chevron would create a nearly uncontestable presumption in favor of an agency's authority to adopt preemptive interpretations of ambiguous statutes. In most cases, the very existence of statutory ambiguity would make it almost impossible for the states to show that Congress had "unambiguously foreclosed" the agency's preemptive ruling. As a federal appellate court explained in a comparable preemption case, such an application of Chevron would be "flatly unfaithful to the principles of administrative law" because "if we were to presume a delegation of power from the absence of an express withholding of such power, agencies would enjoy virtually limitless hegemony."195 Accordingly, the heightened scrutiny applied by the Court in Gonzales and Cuomo should become the governing approach if the Court ultimately selects Chevron as the applicable standard for judicial review of agency preemption claims.

Cuomo and Brand X: Justice Scalia and Justice Thomas also sharply differed in Cuomo as to the binding impact of prior Supreme Court decisions on federal agencies under Chevron.

193 Cuomo, 129 S. Ct. at 2727 (Thomas, J., dissenting in part).

194 Id. at 2733.

195 American BarAss'n v. FTC, 430 F.3d 457, 468 (D.C. Cir. 2005) (internal quotation marks and citation omitted). See supra note 184 (discussing the appellate court's rejection of the FTC's preemption claim). 
Relying on National Cable \& Telecommunications Ass 'n v. Brand X Internet Services, ${ }^{196}$ Justice Thomas contended that the OCC was free under Chevron to adopt its own interpretation of "visitorial powers" and to disregard St. Louis and several other Supreme Court decisions that had previously upheld the authority of state officials to file lawsuits against national banks. Justice Thomas maintained that Brand $X$ made those earlier decisions irrelevant because they did not adopt an "authoritative" construction of 12 U.S.C. $\S 484($ a) that explicitly preserved the states" power of judicial enforcement as an exception to the limitation on "visitorial powers" under $\S 484(\mathrm{a})$. Justice Thomas concluded that none of the cited decisions "addressed the meaning of 'visitorial powers' for purposes of $\S$ 484(a), let alone provided a definitive construction of the statute."197 In his view, "[i]f the Chevron doctrine is to have any interpretive value, an agency's construction of a statute cannot be foreclosed by a prior decision in which the [statutory] provision in question was neither raised by the parties nor passed upon by the court."198 Justice Scalia rejected Justice Thomas' argument based on Brand $X$. In Justice Scalia's view, "St. Louis is relevant to the proper interpretation of 12 U.S.C. $\S 484($ a) . . because it is one in a long and unbroken line of cases distinguishing visitation from law enforcement."199 Although Justice Scalia did not contest the point, it appears that Justice Thomas was mistaken in concluding that the federal statutory limitation on "visitorial powers" was not invoked by the litigants in St. Louis. The summaries of arguments presented by counsel in St. Louis, as published in United States Reports, indicate that both the national bank and the United States as amici curiae argued that Missouri's quo warranto action against the national bank was a violation of the NBA's limitation on the exercise of "visitorial powers." ${ }^{200}$ Thus, St. Louis could

196545 U.S. 967 (2005).

197 Cuomo, 129 S. Ct. 2730 (Thomas, J., dissenting in part).

198 Id. at 2730 n.3.

199 Cuomo, 129 S. Ct. at 2717 n.2 (majority opinion).

200 See St. Louis, 263 U.S. at 641-47 (summaries of arguments for the national bank and the United States). In his dissenting opinion in Cuomo, Justice Thomas cited NYAG Cuomo's reply brief for the proposition that "the [national] bank never raised the "visitorial powers' defense in [St. Louis]." Cuomo, 129 S. Ct. at 2730 n.3 (citing Reply Brief for Petitioner at 6). There appears to be a conflict between the national bank's argument as described by Justice Thomas and the summary of the bank's arguments published in United States Reports. In the published summary, the national bank maintained that Missouri was attempting to 
reasonably be viewed as adopting, by necessary implication, a position that Section 484's

limitation on "visitorial powers" did not preempt the states' authority to enforce valid, non-

preempted state laws by filing lawsuits against national banks.

The debate in Cuomo between Justice Thomas and Justice Scalia over the binding effect of St. Louis was effectively a replay of their dueling opinions in Brand X. Justice Thomas wrote the majority opinion in Brand $X$ while Justice Scalia authored a vigorous dissent. Justice Thomas' majority opinion held that "[b]efore a judicial construction of a statute ... may trump an agency's [interpretation], the court must hold that the statute unambiguously requires the court's construction." 201 In his dissent, Justice Scalia declared that Brand X's concept of "judicial decisions subject to reversal by executive officers" was "bizarre" and "probably unconstitutional" as a violation of separation of powers. ${ }^{202}$ In Justice Scalia's view, "Article III courts do not sit to render decisions that can be reversed or ignored by executive officers."203

Justice Scalia's dissent in Brand X was consistent with his subsequent refusal in Cuomo to allow the OCC to disregard St. Louis and other Supreme Court decisions that had previously upheld the right of state officials to file lawsuits to enforce state laws against national banks. While the majority opinion in Cuomo did not expressly overrule or limit Brand $X$, the two opinions cannot easily be reconciled except on the ground that the agency in Brand $X$ overruled the decision of a court of appeals while the agency in Cuomo disregarded a Supreme Court

exercise a "visitatorial power" which was "forbidden," and the bank cited Rev. Stat. § 5241, the predecess or of 12 U.S.C. $\S 484$ (a). See St. Louis, 263 U.S. at 643 (summary of argument for the bank). The summary of argument for the United States published in United States Reports included an assertion that Missouri's quo warranto proceedings were "an obvious attempt to exercise visitatorial powers" that "our system of government forbids." See id. at 645 (summary of argument for the United States). The summary of the United States' argument also included citations to (i) Guthrie v. Harkness, 199 U.S. 148 (1905), in which the Supreme Court construed the meaning of the prohibition on "visitorial powers" in Rev. Stat. $\S 5241$, and (ii) Rev. Stat. $\S 5239 \& 5240$, the predecessors of 12 U.S.C. 93(a) \& 481, which define the visitorial powers of the OCC. See St. Louis, 263 U.S. at 645, 647 (summary of argument for the United States). Thus, the published summaries of arguments for the national bank and the United States in St. Louis strongly indicate that both parties raised the issue of whether Missouri's judicial enforcement proceedings were barred by the NBA's limitation on "visitorial powers."

201 Brand $X, 545$ U.S. at 985.

${ }^{202} I d$. at 1016-17 (Scalia, J., dissenting).

${ }^{203}$ Id. at 1017 (citing Southern Air Lines, Inc. v. Waterman, 333 U.S. 103 (1948)). 
precedent. It therefore remains to be seen whether Cuomo will be interpreted in the future as barring federal agencies from adopting interpretations of "ambiguous" statutes that conflict with previous Supreme Court (as opposed to appellate court) decisions. ${ }^{204}$

\section{The Presumption against Preemption and the Doubtful Relevance of Locke and Smiley}

Another recurring issue in agency preemption cases is whether an agency's claim to judicial deference under Chevron must overcome a presumption against preemption. As discussed above, Justice Stevens strongly endorsed the applicability of a presumption against preemption in both his dissenting opinion in Watters and his majority opinion in Wyeth. ${ }^{205}$

In Cuomo, Justice Scalia found it "unnecessary" to invoke a presumption against preemption in order to strike down the OCC's regulation. ${ }^{206}$ However, he emphasized that "the incursion that the [OCC's] regulation makes upon traditional state powers [should not] be

minimized." 207 He pointed out that "the [OCC] was not given authority to enforce nonpre-empted state laws [against national banks] until 1966," and he therefore rejected Justice Thomas' claim that the "historic police powers of the States" were unaffected by the OCC's regulation. ${ }^{208}$

Similarly, in Gonzales the Supreme Court found it "unnecessary even to consider the application of . . presumptions against pre-emption" in concluding that Congress "[did] not authorize the Attorney General to bar dispensing controlled substances for assisted suicide in the face of a state medical regime permitting such conduct." ${ }^{209}$ The Court rejected the Attorney General's claim that the governing federal statue "impliedly authorizes ... an expansive federal authority to regulate medicine," in view of the statute's "silence on the practice of medicine

204 Justice Stevens filed a concurring opinion in Brand X, in which he agreed that "a court of appeals' interpretation of an ambiguous statute does not foreclose a contrary reading by the agency." However, Justice Stevens stated that the same result "would not necessarily be applicable to a decision by this Court that would presumably remove any preexisting ambiguity." Id. at 1004 (Stevens, J., concurring). Justice Stevens' concurrence suggests that he might not have supported the outcome in Brand $X$ if the agency had disregarded a construction of the applicable statute by the Supreme Court instead of a court of appeals.

205 See supra notes 138-39, 147, 173 and accompanying text.

206 Cuomo, 129 S. Ct. at 2720 (majority opinion).

207 Id.

208 Id. (quoting Rice, 331 U.S. at 230).

209 Gonzales, 546 U.S. at 274-75. 
generally and its recognition of state regulation of the medical profession."210 Thus, in both Cuomo and Gonzales, the Court recognized the potential applicability of a presumption against preemption in determining whether to defer to a federal agency's preemptive ruling under Chevron. However, the Court did not consider it necessary in either case to invoke the presumption, because the evidence of congressional intent was sufficiently persuasive on its own to defeat the agency's claim of preemptive authority.

The Inapplicability of Locke to Fields of Dual Federal-State Regulation: In his dissenting opinion in Cuomo, Justice Thomas contended, based on United States v. Locke, ${ }^{211}$ that a presumption against preemption should never be applied in construing the preemptive effect of the NBA. ${ }^{212}$ However, Justice Thomas' reliance on Locke was misplaced. In Locke the Supreme Court struck down state laws that imposed requirements and restrictions on oil tankers operating in navigable waterways. The Court refused to apply "an 'assumption' of "nonpre-emption" in Locke with respect to the field of "national and international maritime commerce," because "Congress has legislated in the field from the earliest days of the Republic" and has consistently expressed its desire to establish a "uniformity of regulation for maritime commerce."213 Thus, Locke involved a field of commerce in which the federal government exercised near-monolithic control and left little room for state involvement. In contrast, the Court held in Atherton that federal policy did not require any "uniformity" of treatment for federally-chartered banks, in view of the long history of supplem ental state regulation of national banks. Accordingly, Atherton refused to adopt a federal common-law rule for federally-chartered banks that would override state-law standards governing fiduciary duties of bank directors . ${ }^{214}$

210 Id. at $273,272$.

211529 U.S. 89 (2000).

212 Justice Thomas pointed out that Congress has legislated with regard to national banks since "the earliest days of the Republic," and he therefore argued that a presumption against preemption should be rejected in interpreting the NBA for the same reason that Locke held such a presumption to be inapplicable in construing federal maritime law. Id. at 2732 (Thomas, J., dissenting in part) (quoting Locke, 529 U.S. at 108).

213 Locke, 529 U.S. at 108; see also id. at 109 (explaining that the governing federal statutes mandated "uniform, national rules regarding general tanker design, operation, and seaworthiness").

214 Atherton, 519 U.S. at 219-26. 
Congress expressed its strong support for the continuing application of state laws to national banks when it passed the Riegle-Neal Interstate Banking and Branching Efficiency Act of 1994, 108 Stat. 2338 (Riegle-Neal Act). The Riegle-Neal Act requires interstate branches of national banks to comply with host state laws in four broadly-defined areas - community reinvestment, consumer protection, fair lending and intrastate branching - unless such laws discriminate against national banks or are otherwise preempted by federal law. 12 U.S.C. $\S$ 36(f)(1)(A). In explaining why state laws should generally apply to national banks, the conference report on the Riegle-Neal Act declared:

States have a strong interest in the activities and operations of depository institutions doing business within their jurisdictions, regardless of the type of the charter an institution holds. In particular, States have a legitimate interest in protecting the rights of their consumers, businesses and communities. . . .

Under well-established judicial principles, national banks are subject to State law in many significant respects. . . Courts generally use a rule of construction that avoids finding a conflict between the Federal and State law where possible. The [Riegle-Neal Act] does not change these judicially established principles. ${ }^{215}$

The Riegle-Neal conference report thus endorsed a judicial "rule of construction" that closely resembles a presumption against preemption. The Riegle-Neal conference report - read in context with Atherton and previous Supreme Court decisions (including St. Louis, Lewis and Luckett) - demonstrates that Congress has preserved a significant, supplemental role for the states in regulating national banks. The history of dual federal-state regulation of national banks stands in sharp contrast to Congress' preclusion of any substantial role for the states in regulating maritime commerce. Accordingly, the reasoning in Locke is clearly inapplicable to preemption cases arising under the NBA. ${ }^{216}$

\footnotetext{
${ }^{215}$ H.R. Rep. No. $103-651$, at 53 (1994) (Conf. Rep.), reprinted in 1994 U.S. Code Congressional and Administrative News 2068, 2074.

${ }^{216}$ Wilmarth, supra note 12 , at 288-89, 245-71. As previously noted, Justice Scalia observed in Cuomo that the OCC "was not given authority to enforce nonpre-empted state laws [against national banks] until 1966," while "States ... have always enforced their general laws against national banks - and have enforced their banking-related laws against national banks for at least 85 years." Cuomo, $129 \mathrm{~S}$. Ct. at 2720. In response to Justice Thomas' invocation of Locke, Justice Scalia remarked that "[a] power first exercised [by the OCC] during the lifetime of every current Justice is hardly involvement 'from the earliest days of the Republic." Id. (quoting Locke, 529 U.S. at 108).
} 
Similarly, in Wyeth Justice Stevens rejected the argument that "the presumption against pre-emption should not apply to this case because the Federal Government has regulated drug labeling for more than a century." 217 Justice Stevens explained that "the presumption [against preemption] accounts for the historic presence of state law" in a particular field and "does not rely on the absence of federal regulation." He further maintained that a presumption against preemption was warranted in Wyeth because "Congress has indicated its awareness of the operation of state law in a field of federal interest, and has nonetheless decided to stand by both concepts and to tolerate whatever tension there [is] between them."218 Thus, Wyeth confirms that Locke does not apply to a field of activity with a strong tradition of concurrent state regulation, even if the federal government has a major presence or even the predominant role in regulating that field. In view of Congress' continuing support for the states' supplemental role in regulating national banks, a presumption against preemption should be applied in future cases raising preemption claims under the NBA.

The Questionable Relevance of Smiley after Cuomo: In Cuomo, Justice Thomas and Justice Scalia also disagreed about whether the OCC's challenged regulation should be viewed as preemptive in the first place. In Smiley v. Citibank (South Dakota), N.A., ${ }^{219}$ the Supreme Court held (in an opinion written by Justice Scalia) that an OCC regulation defining the term "interest" for purposes of 12 U.S.C. $\S 85$ did not preempt state law. As noted in Smiley, a 1978 decision of the Supreme Court had previously held that $\S 85$ preempted state usury laws as a statutory matter. Smiley therefore concluded that the OCC's regulation only defined "the substantive (as opposed

217 Wyeth, 129 S. Ct. at 1195 n.3.

${ }_{218}$ Id. at 1200 (quoting Bonita Boats, Inc. v. Thunder Craft Boats, Inc., 489 U.S. 141, 166-67 (1989) (internal quotation marks omitted)). Justice Stevens did not mention Locke in his opinion for the Court in Wyeth. However, Justice Alito invoked Locke in his dissenting opinion to support his contention that the Court should not have applied a presumption against preemption in Wyeth. Id. at $1229 \mathrm{n} .14$ (Alito, J., dissenting) (quoting Locke). Thus, it could be argued that Justice Stevens' opinion in Wyeth implicitly rejected the applicability of Locke to the labeling of prescription drugs because that was a field in which Justice Stevens found a "historic presence of state law" as well as evidence of "Congress' decision not to pre-empt [state] common-law tort suits." Id. at $1195 \mathrm{n} .3,1202$ (majority opinion).

219517 U.S. 735 (1996). 
to pre-emptive) meaning of [§ 85]."220 Accordingly, Smiley concluded that the OCC's regulation was not preemptive and did not need to overcome any presumption against preemption in order to receive deference under Chevron.

Relying on Smiley, Justice Thomas argued in Cuomo that 12 C.F.R. $§ 7.4000$ was not preemptive because the rule merely interpreted "an ambiguous statutory term" (namely, "visitorial powers") in order to "clarify the preemptive scope of enacted federal law.",221 However, as Nina Mendelson has pointed out, the reasoning in Smiley is open to serious question, because the OCC's expansive "interpretation" of the statutory term "interest" for purposes of $\S 85$ "effectively broadened the statute's preemption of state [usury] law."222

Justice Scalia insisted in Cuomo that the OCC's regulation was indeed preemptive. As he pointed out, "[a]ny interpretation of 'visitorial powers' necessarily 'declares the pre-emptive scope of the NBA,' . . If that is not pre-emption, nothing is."223 Thus, Justice Scalia essentially repudiated his prior reasoning in Smiley. Based on Cuomo, litigants can now argue that an agency regulation that defines the "meaning" of a preemptive statute in a way that expands the statute's reach should itself be viewed as preemptive. Accordingly, for the reasons discussed above, such a rule should receive a lower level of judicial deference and should be subject to the presumption against preemption.

\section{Cuomo's Implications for the Future of the Dual Banking System and Consumer Protection}

For at least three reasons, Cuomo is likely to have a significant impact on future court cases and legislative proposals dealing with the dual banking system and consumer protection. First, the decision affirms the right of state officials to seek judicial enforcement of valid, nonpreempted state laws against national banks. Cuomo provides a significant boost to the dual banking system and consumer protection by ensuring that national banks, like other lenders, are

220 Id. at 744 (citing and quoting Marquette National Bank of Minneapolis v. First of Omaha Service Corp., 439 U.S. 299, 318-19 (1978)).

221 Cuomo, 129 S. Ct. at 2732-33 (Thomas, J., dissenting in part).

222 Nina A. Mendelson, "Chevron and Preemption," 102 Michigan Law Review 737, 739-40 (2004).

223 Cuomo, 129 S. Ct. at 2721 (majority opinion) (quoting id at 2732 (Thomas, J., dissenting in part)). 
subject to judicial enforcement of applicable state laws by state officials. In contrast, a victory by the OCC and the Clearing House in Cuomo (i) would have encouraged state banks to convert to national charters to avoid exposure to state enforcement proceedings, and (ii) would have made it much more difficult politically for states to enact and implement new laws protecting consumers of financial services, because state officials would have been barred from enforcing such laws against national banks and their operating subsidiaries.

Second, Cuomo will shift the focus of future preemption cases involving national banks to the question of which state laws apply to national banks, and it will also encourage legal challenges to the validity of the OCC's substantive preemption rules. In 2004, the OCC adopted sweeping regulations that purport to preempt state laws in four broadly-defined areas - real estate lending, other lending, deposit-taking, and other federally-authorized "activities." In all four areas, the OCC's rules (i) preempt state laws if they "obstruct, impair, or condition a national bank's ability to fully exercise its powers to conduct activities authorized under Federal law," and (ii) allow state laws to apply to national banks only if such laws "establish the legal infrastructure that makes [it] practicable" for national banks to conduct their federally-authorized activities. ${ }^{224}$ The practical effect of the OCC's "infrastructure" theory, as embodied in the 2004 preemption rules, is to establish a regime of "de facto field preemption," in which "only those state laws that promote the ability of national banks to [conduct a banking business] will remain applicable.,"225

Cuomo strikes a significant blow at the OCC's claim of exclusive preemptive authority over the banking activities of national banks. As previously discussed, Cuomo declared that "States ... have always enforced their general laws against national banks - and have enforced their banking-related laws against national banks for at least 85 years, as evidenced in St. Louis." ${ }^{226}$ Cuomo thus reaffirmed the presumptive applicability of state laws to national banks,

${ }^{224} 12$ C.F.R. $\S \S 7.4007-7.4009 \& 34.4$; 69 Fed. Reg. 1904, $1912-13$ (2004); see Wilmarth, supra note 12 , at 233-36 (describing the OCC's 2004 preemption rules). For a comprehensive critique of the legal rationale for the OCC's 2004 preemption rules, see generally Wilmarth, supra note 12.

225 Wilmarth, supra note 12, at 235-37. 298-99.

226 Cuomo, 129 S. Ct. at 2720. 
and Cuomo also vitiated the precedential force of Watters' arguably broader view of NBA preemption.

In addition, Cuomo addressed and rejected the OCC's assertions that (i) the NBA generally preempts state laws that "affect the content or extent of the Federally-authorized business of banking," and (ii) the NBA permits the application of state law only if it "establishes the legal infrastructure that surrounds and supports the ability of national banks ... to do business." 227 In Cuomo, the Court declared that the OCC's asserted "distinction between 'implementation' of 'infrastructure' and judicial enforcement of other [state] laws can be found nowhere within the text of the [NBA]. This passage ... attempts to do what Congress declined to do: exempt national banks from all state banking laws, or at least enforcement of those laws." ${ }^{228}$ Cuomo creates serious doubts about the validity of the OCC's substantive preemption rules, because those rules rely on the same purported distinction between nonpreempted state "infrastructure" laws and other state laws that the OCC claims are preempted if they place any "condition" on authorized national bank activities. ${ }^{229}$

Third, Cuomo dramatically changes the legal status quo for debates about the adoption of new federal legislation to provide greater protection for consumers of financial services. In June 2009 , the Treasury Department published a comprehensive plan for financial regulatory reform. ${ }^{230}$ One of the key elements of the Treasury plan is its proposal for a new "Consumer Financial Protection Agency" (CFPA). The proposed CFPA would have broad authority to issue and enforce consumer protection regulations applicable to all providers of financial services, including national banks and federal thrifts. ${ }^{231}$

22769 Fed. Reg. 1895, 1896 (2004), quoted in Cuomo, 129 S. Ct. at 2719.

228 Cuomo, 129 S. Ct. at 2720.

229 See 69 Fed. Reg. at 1912-13 (asserting that (i) "state laws do not apply to national banks if they obstruct, impair, or condition a national bank's ability to fully exercise [its] powers," and (ii) state laws may apply to national banks if they "do not regulate the manner or content of the banking business authorized for national banks, but rather establish the legal infrastructure that makes practicable the conduct of that business").

${ }^{230}$ U.S. Dept. of the Treasury, Financial Regulatory Reform: A New Foundation (June 2009).

231 Id. at 55-70. 
In July 2009, Representative Barney Frank, Chairman of the House Financial Services Committee, introduced a proposed bill (H.R. 3126) to create the CFPA. Like the Treasury plan, Subtitle D of H.R. 3126 would preserve the states' authority to enact laws that give additional protections to consumers beyond those established by the CFPA's regulations. Such supplemental state laws would be applicable on a nondiscriminatory basis to all financial service providers, including national banks, federal thrifts and their subsidiaries and agents. ${ }^{232}$ In addition, Subtitle D would empower state attorneys general, after consulting with the CFPA, to bring judicial proceedings to enforce applicable state laws against all financial service providers. ${ }^{233}$

Prior to the Supreme Court's decision in Cuomo, the OCC and national banks might have claimed - with some arguable support from Watters - that Subtitle D of H.R. 3126 would constitute a significant departure from the legal status quo governing the dual banking system. After Cuomo, however, state officials and consumer groups have a persuasive basis for their position that Subtitle D represents an appropriate congressional endorsement of the states' legitimate role in regulating financial institutions and protecting consumers.

${ }^{232}$ Id. at 60-61; H.R. 3126, 111 th Congress, 1 st Session, $\S \S 141-48$ (original bill as introduced on July 8, 2009).

${ }^{233}$ H.R. 3126, supra note 232, § $\$ 142-48$. 